\title{
RESEARCH
}

Open Access

\section{Rhizosphere community selection reveals bacteria associated with reduced root disease}

\author{
Chuntao Yin ${ }^{1}$, Juan M. Casa Vargas ${ }^{1}$, Daniel C. Schlatter ${ }^{2}$, Christina H. Hagerty ${ }^{3}$, Scot H. Hulbert ${ }^{1}$ and \\ Timothy C. Paulitz $2^{*}$ (I)
}

\begin{abstract}
Background: Microbes benefit plants by increasing nutrient availability, producing plant growth hormones, and protecting against pathogens. However, it is largely unknown how plants change root microbial communities.

Results: In this study, we used a multi-cycle selection system and infection by the soilborne fungal pathogen Rhizoctonia solani AG8 (hereafter AG8) to examine how plants impact the rhizosphere bacterial community and recruit beneficial microorganisms to suppress soilborne fungal pathogens and promote plant growth. Successive plantings dramatically enhanced disease suppression on susceptible wheat cultivars to AG8 in the greenhouse. Accordingly, analysis of the rhizosphere soil microbial community using deep sequencing of 165 rRNA genes revealed distinct bacterial community profiles assembled over successive wheat plantings. Moreover, the cluster of bacterial communities formed from the AG8-infected rhizosphere was distinct from those without AG8 infection. Interestingly, the bacterial communities from the rhizosphere with the lowest wheat root disease gradually separated from those with the worst wheat root disease over planting cycles. Successive monocultures and application of AG8 increased the abundance of some bacterial genera which have potential antagonistic activities, such as Chitinophaga, Pseudomonas, Chryseobacterium, and Flavobacterium, and a group of plant growth-promoting (PGP) and nitrogen-fixing microbes, including Pedobacter, Variovorax, and Rhizobium. Furthermore, 47 bacteria isolates belong to 35 species were isolated. Among them, eleven and five exhibited antagonistic activities to AG8 and Rhizoctonia oryzae in vitro, respectively. Notably, Janthinobacterium displayed broad antagonism against the soilborne pathogens Pythium ultimum, AG8, and R. oryzae in vitro, and disease suppressive activity to AG8 in soil.
\end{abstract}

Conclusions: Our results demonstrated that successive wheat plantings and pathogen infection can shape the rhizosphere microbial communities and specifically accumulate a group of beneficial microbes. Our findings suggest that soil community selection may offer the potential for addressing agronomic concerns associated with plant diseases and crop productivity.

Keywords: Microbial community, Rhizoctonia solani, Disease suppression, Antagonism, Beneficial bacteria

\footnotetext{
* Correspondence: timothy.paulitz@usda.gov

USDA-ARS, Wheat Health, Genetics and Quality Research Unit, Washington

State University, Pullman, WA 99164-6430, USA

Full list of author information is available at the end of the article
}

\section{$\triangle B M C$}

C C The Author(s). 2021 Open Access This article is licensed under a Creative Commons Attribution 4.0 International License, which permits use, sharing, adaptation, distribution and reproduction in any medium or format, as long as you give appropriate credit to the original author(s) and the source, provide a link to the Creative Commons licence, and indicate if changes were made. The images or other third party material in this article are included in the article's Creative Commons licence, unless indicated otherwise in a credit line to the material. If material is not included in the article's Creative Commons licence and your intended use is not permitted by statutory regulation or exceeds the permitted use, you will need to obtain permission directly from the copyright holder. To view a copy of this licence, visit http://creativecommons.org/licenses/by/4.0/. The Creative Commons Public Domain Dedication waiver (http://creativecommons.org/publicdomain/zero/1.0/) applies to the data made available in this article, unless otherwise stated in a credit line to the data. 


\section{Background}

It is widely accepted that the rhizosphere microbial communities are tightly associated with plant roots $[1,2]$. The microbiota can be harmful or beneficial to the host plant. Soilborne pathogens reduce plant growth, cause yield loss, and threaten agricultural production. However, nonpathogenic microbes, such as beneficial and mutualistic microbes, can promote plant growth by increasing nutrient availability, producing plant hormones, enhancing tolerance to abiotic stresses, and adapting to environmental variations [2-7]. Moreover, beneficial microbes can protect plants against pathogens through antagonism, competition, or by interfering with the host immunity to establish a mutualistic association with the host [8-17]. Recent work has suggested that members of the plant microbiota can enhance host immune functions [18]. Therefore, understanding how root microbiota influence plant performance is of great agronomic interest.

In return, microbial community establishment in the rhizosphere is not random but rather driven by host plant selection $[1,14,15]$. Plants have the capacity to change soil microbiota by secreting bioactive molecules into the rhizosphere. Different plant species can influence microbiome composition and structure, and some species appear to have a much stronger association with specific microbes than others $[19,20]$. The effects of plant genotype on the rhizobiome have been reported in Arabidopsis, cucumber, bean, Brachypodium, maize, barley, and wheat [21-26], though the intra-specific genetic contribution to microbiome assembly is relatively low. Decades of research have shown that plant genotype/ species and developmental stages impact the qualitative and quantitative composition of plant root exudates [21, 27-30]. The plant may not be the only determinant in root exudates. Various abiotic and biotic factors, such as soil type and pathogens, in the surrounding environment also influence root exudates [28, 31]. Root exudates are released into the rhizosphere where they are crucial in attracting and selecting microorganisms, thus altering the composition and structure of rhizosphere microbial communities in a plant-specific manner [32]. Plants specifically attract beneficial microbes through plant rootderived signals [33]. Furthermore, plant immune systems might promote the accommodation and growth of beneficial microbes and contribute to the maintenance of a stable microorganism community, thus playing an important part in regulating variations in microbiota composition [34]. Tkacz et al. [28] used a successive planting approach to investigate shifts in the microbial populations in the soil and found that Arabidopsis, Medicago, and Brachypodium select soil microbiomes differently. Similarly, Panke-Buisse et al. [35] revealed distinct microbiota profiles assembled by Arabidopsis thaliana at various flowering time treatments using a multigeneration experimental system. However, the effects of plants on the composition of rhizosphere communities are highly complex and dynamic. Our understanding of how plants shape rhizosphere microorganism assembly is still not fully understood.

Microbial pathogens can cause severe damage to plant roots resulting in significant agricultural yield loss. Intriguingly, continuous growth of a susceptible plant in the field and a disease outbreak often induce suppression of soilborne fungal pathogens by altering soil microbial community. And similar phenomena appear to occur in different soils from geographically distinct regions that suggests disease suppression is developed through similar mechanisms [16, 36, 37]. Several studies revealed that plants respond to pathogen attack by producing chemical compounds which attract a suit of beneficial microorganisms [38, 39]. Similarly, Rudrappa et al. [31] demonstrated that Arabidopsis thaliana selectively recruit the beneficial bacterium Bacillus subtilis when challenged with pathogen Pseudomonas syringae pv. tomato DC3000. Microbial network analysis found microbial taxa that were positively associated with the absence of root infection by Rhizoctonia solani [40]. In Dudenhöffer's study, barley plants manipulated their rhizosphere community to recruit antifungal microbes in response to Fusarium graminearum attack [41]. Taken together, these discoveries indicate a tight linkage between the microbial community in planta and pathogen infection and provide the possibility that plants recruit disease-suppressive microbes in response to pathogen attack.

In this study, we conducted multi-cycle wheat plantings with or without Rhizoctonia solani AG8 infection to address (1) whether multi-cycle wheat plantings and pathogen infection influence the structure of rhizosphere bacterial communities; (2) whether the assembly of rhizosphere bacterial communities affect plant disease development caused by AG8; and (3) whether microbial recruitment is associated with antifungal activities. Overall, we hypothesized that plant rhizosphere succession and interaction of host and soilborne pathogens might manipulate their rhizosphere microbiome structure, and recruit/enrich beneficial or antagonistic microorganisms to suppress pathogens in the rhizosphere, eventually providing a new opportunity to suppress root disease and increase crop production.

\section{Methods}

\section{Plant and growth conditions}

The wheat cultivar Alpowa, highly susceptible to Rhizoctonia solani AG8, was used in this study. All wheat seeds were derived from the same seed source to reduce plant variation. Seeds were treated with $5 \%$ sodium 
hypochlorite for 3 mins for surface disinfestation and rinsed three times with sterilized $\mathrm{ddH}_{2} \mathrm{O}$ before germination. All plants were grown in a growth chamber in 16/ $8 \mathrm{~h} \mathrm{light/darkness} \mathrm{at} 16{ }^{\circ} \mathrm{C}$.

\section{Multi-cycle wheat plantings and microbiome selection}

The soil used in this study was collected from the Washington State University Dryland Research Station near

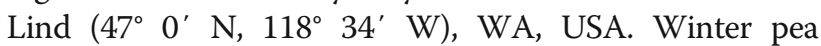
(Pisum sativum L.) was planted in September 2016 at the study site and plowed down in the summer of 2017. The soil was a Shano silt loam as described by Sharratt and Schillinger [42]. All soil was transferred to the greenhouse and air-dried at room temperature, pooled, and sieved through a $0.5-\mathrm{cm}$ mesh screen to remove plant debris and stored in a cold room $\left(4^{\circ} \mathrm{C}\right)$ for further use.

The inoculum of $R$. solani AG8 was prepared with twice-autoclaved millet seeds. Briefly, AG8 was grown in potato dextrose agar medium (PDA, Sigma-Aldrich, St. Louise, MO) for one week. The inoculated fungal agar was then added into autoclaved millet seeds in a 1-L Erlenmeyer flask and kept at room temperature in the dark for 3-4 weeks. Flasks were shaken every week to ensure even colonization of the millet seeds. Colonized millet seeds were air-dried and ground. The inoculum density was enumerated by fungal colony counts before use by dilution plating on water agar.
Multi-cycle wheat plantings were conducted as described in Fig. 1. Briefly, for the first cycle (cycle 1) of plant growth, the Lind soil was amended with ground millet inoculum of AG8 to final concentration 200 propagules per gram (ppg) of soil. Twenty plastic cones (2.5 $\mathrm{cm}$ in diameter and $16.5 \mathrm{~cm}$ long) were filled with $120 \mathrm{~g}$ of Rhizoctonia-inoculated soil. Four cones filled with 120 $\mathrm{g}$ of soil and amended with ground autoclaved millet seeds without Rhizoctonia served as controls. In total, 24 cones filled with Rhizoctonia-inoculated soil or without Rhizoctonia-inoculated control soil were included. Three pre-germinated wheat seeds (cultivar Alpowa) were sown in each cone. Cones were arranged in a randomized complete block design in plastic racks and incubated in a growth chamber in 16/8 h light/darkness at $16{ }^{\circ} \mathrm{C}$. For the first 4 days, sample cones were covered with plastic. After the plastic was removed, each cone received $10 \mathrm{ml}$ of water twice a week and diluted (1:3 [vol/vol]) Hoagland's solution once a week. After 4 weeks, the wheat seedlings were removed from the cones and roots were shaken to remove adhering soil. Roots were cut and placed in a $250-\mathrm{ml}$ sterile flask. Soil slurries were prepared with $1 \mathrm{~g}$ fresh roots and $6 \mathrm{ml}$ of sterile double-distilled water at a ratio of 1:6, then vortexed for $30 \mathrm{~s}$ until the roots were visibly clear from adhering soil. The plants were evaluated for Rhizoctonia disease root rot severity on a scale of 0 to 8 as described previously [43]. Two milliliters of the soil slurries were stored at -

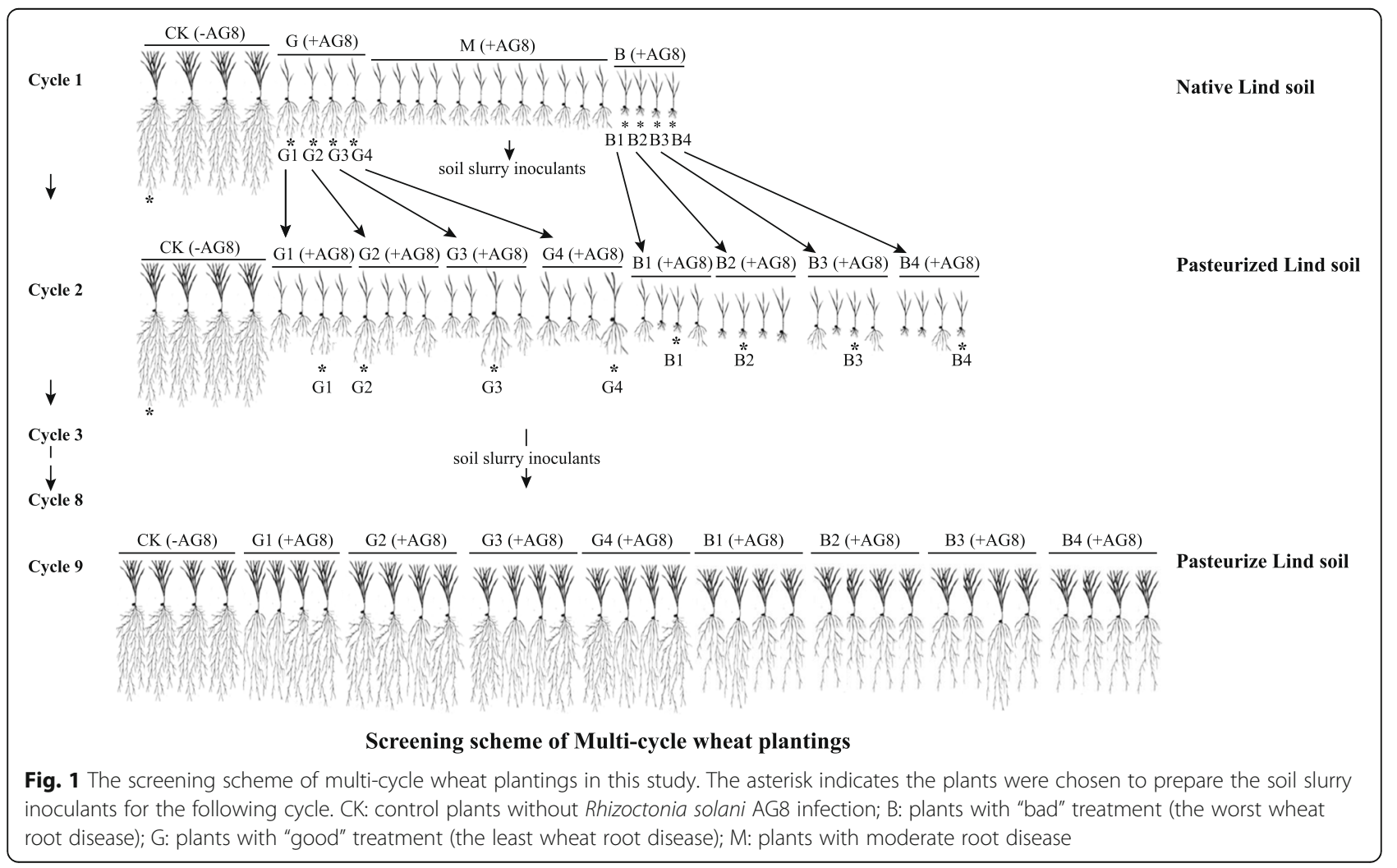


$20{ }^{\circ} \mathrm{C}$ for DNA extraction and designated as cycle 1 samples. Among them, the soil slurries from plant growth in Rhizoctonia-inoculated soil and without Rhizoctonia-inoculated control soil were designated as " $\mathrm{R}$ " and "CK," respectively. Furthermore, four soil slurries from plants with the least Rhizoctonia disease symptoms and four with the worst disease symptoms chosen from the 20 " $R$ " replicates were used as microbial inoculum for the following cycle and designated as "good" (G; least disease) and "bad" (B; worst disease) treatments, respectively. The soil slurries from plants with moderate disease symptoms (M) were not kept. One soil slurry was chosen from the four "CK" replicates. Starting from the second cycle (cycle 2), the Lind soil was pasteurized at $60{ }^{\circ} \mathrm{C}$ for $30 \mathrm{~min}$ to reduce the inference from other microorganisms and air-dried at room temperature. The pasteurized soil amended with 200-ppg AG8 was divided into eight 480-g units for the treatment soil and one 480 $\mathrm{g}$ of pasteurized soil amended with ground autoclaved millet without Rhizoctonia served as control, then each unit received $48 \mathrm{ml}$ of the corresponding treatment soil slurry inoculants from cycle 1 , respectively. One hundred twenty grams of each unit soil was added to four individual cones, respectively. There were 36 cones in total, four "good" (G) and four "bad" (B) treatments, each of them having four sub-replicates, and four controls (CK). A subsequent cycle of wheat growth was initiated. After 4 weeks of growing, similar to cycle 1, the plants were evaluated for Rhizoctonia disease symptoms. Seedlings with the least Rhizoctonia disease symptoms were chosen from four sub-replicates of "good" treatments, and the worst Rhizoctonia disease symptom seedlings were chosen from four sub-replicates of "bad" treatments. One cone of seedlings was chosen from four control replicates. Then, the soil slurry inoculants were prepared from those chosen plant roots for the following cycle. Two milliliters of the rhizosphere soil slurries from each sample were stored at $-20{ }^{\circ} \mathrm{C}$ for rhizosphere soil DNA extraction and designated as cycle 2 samples. Cycle 3 was performed as cycle 2 . Over nine cycles, $2 \mathrm{ml}$ of the rhizosphere soil slurries were stored at $-20{ }^{\circ} \mathrm{C}$ for soil DNA extraction and designated as cycle 9 samples. In addition, the other $2 \mathrm{ml}$ of the rhizosphere soil slurries from the cycles $5,6,7,8$, and 9 were used for bacteria isolation.

\section{DNA extraction and sequencing}

DNA was extracted from $2 \mathrm{ml}$ of the rhizosphere soil of cycle 1,2, and 9 samples using a DNeasy PowerSoil kit (Qiagen, Carlsbad, CA) with the alternative protocol for wet soil samples and a FastPrep bead beater (MP Biomedical, Santa Ana, CA) using the "soil" program. The DNA was quantified using a Nanodrop spectrophotometer (Thermo Fisher Scientific, Waltham, MA) and sent to the University of Minnesota Genomics Center (UMGC) for amplification and sequencing. The V1-V3 hypervariable region of the $16 \mathrm{~S}$ rRNA gene was amplified with primers MN_27F (5'-AGAGTTTGATCM TGGCTCAG-3') and MN_534R (5'-ATTACCGCGGC TGCTGG-3') using a dual-indexing approach. The detailed information on PCR was provided in Additional File 1 . Then, the amplicons were pooled, size selected, spiked with 20\% PhiX and sequenced for paired end $(2 \times$ $300 \mathrm{bp}$ ) on the Illumina MiSeq platform. The raw sequence data was deposited in the Small Read Archive of the National Center for Biotechnology Information under accession number PRJNA578725.

\section{Sequence processing}

The sequence processing was conducted using USEARCH (version 11 [44];) to denoise sequences and define operational taxonomic units (OTUs). Specifically, reads were merged (maximum differences $=15$, minimum percent ID $=80 \%$ ) and primers were trimmed from the end of each read. To generate high-quality reads for denoising, reads were filtered with a maximum expected error rate of 1 and unique sequences were denoised using the "unoise3" algorithm. An OTU table was constructed by mapping all sequences to OTU representatives at a 97\% similarity threshold. Taxonomy was assigned to OTUs using the SINTAX algorithm [45] with an $80 \%$ confidence threshold to the Ribosomal Database Project reference database (version 16) [46]. Sequences that could not be classified as bacteria and those identified as Streptophyta were removed and OTU tables were subsampled in the place of rarefied sequences for all analyses unless otherwise noted.

\section{Isolation and characterization of bacteria from rhizosphere soil}

Bacteria were isolated from rhizosphere soil collected from cycles 5, 6, 7, 8, and 9, as described by Yin et al. [43]. Briefly, the rhizosphere soil slurries were serially diluted to 10-fold in 1.7-ml Eppendorf tubes. The resulting dilutions were plated on 1/4 tryptic soy agar (TSA) medium (Becton Dickinson [BD], Franklin Lakes, NJ). Because some bacteria grow poorly in the TSA medium, an R2A medium (ThermoFisher Scientific, Waltham, MA) was also used. Plates were incubated in the dark at room temperature and bacterial colonies in the plates were checked two days later. Representative colony types were picked from the most dilute plate and re-streaked on the plates with a new medium to obtain pure colonies. Colony PCR was performed with the primers MN_27/MN_543R as follows: an initial denaturation at $95{ }^{\circ} \mathrm{C}$ for $10 \mathrm{~min}, 30$ cycles of $95^{\circ} \mathrm{C}$ for $1 \mathrm{~min}, 55^{\circ} \mathrm{C}$ for $1 \mathrm{~min}$, and $72{ }^{\circ} \mathrm{C}$ for $1 \mathrm{~min}$, with a final extension at 72 ${ }^{\circ} \mathrm{C}$ for $5 \mathrm{~min}$. The PCR products were analyzed on $1.5 \%$ 
agarose gel electrophoresis and the approximate 600-bp amplicons were purified with the GeneJET PCR Purification Kit (ThermoFisher Scientific, Waltham, MA). The purified amplicons were sequenced by Elim Biopharmaceuticals, Inc (Hayward, CA). The sequences were blasted to the NCBI database and the Ribosomal Database Project reference database (version 16) for bacterial taxa classification. The sequence of individual bacterial isolates was blasted to the sequences of OTU representatives derived from 16S rRNA sequences and assigned to the corresponding OTU. Identified bacterial isolates were stored in $25 \%$ glycerol at $-80{ }^{\circ} \mathrm{C}$ for further use.

\section{In vitro antagonistic activities of bacteria against soilborne pathogens}

The antagonistic activities of bacterial isolates against soilborne pathogens, including fungi Rhizoctonia solani AG8, $R$. oryzae, and oomycete Pythium ultimum, were tested by in vitro dual culture assays on 1/4 TSA or R2A medium, as described by Yin et al. [43]. For negative controls, petri dishes were inoculated only with an agar disc colonized with the tested pathogens. Paired culture plates were placed in the dark and incubated at $25{ }^{\circ} \mathrm{C}$ until the TSA or R2A medium for the controls was completely covered with pathogen mycelia. The radial growth of the pathogen was measured with a ruler. The percent inhibition of radial growth was calculated as follows: $100 \times[(R 1-R 2) / R 1]$, where $R 1$ was the radial growth of pathogens in the control and R2 was the radial growth of pathogens in the dual culture with the antagonist. The experiment was repeated three times with three replicates of each treatment. Bacterial isolates that showed antagonistic activity were selected for further assays.

\section{Greenhouse suppression assays}

Bacteria that showed antagonistic activity in dual culture assay were tested against $R$. solani AG8 in soil in the greenhouse. The Lind soil was amended with ground millet inoculum of AG8 to a final concentration of 100 ppg of soil. Plastic cones $(2.5 \mathrm{~cm}$ in diameter and 16.5 $\mathrm{cm}$ long) were filled with $120 \mathrm{~g}$ of Rhizoctonia-inoculated soil. The bacteria were scraped from 1/4 TSA plates, suspended in double-distilled water, and centrifuged for $3 \mathrm{~min}$ at 13,000 rpm. The pellet was resuspended in sterile $\mathrm{ddH}_{2} \mathrm{O}$ and adjusted to the optical density OD600 value of 1.0. Three-day pre-germinated wheat seeds were incubated in the bacterial slurries for $30 \mathrm{~min}$ at $25{ }^{\circ} \mathrm{C}$, while the control seeds were treated with an equal amount of sterile water before planting. Wheat seeds were treated with the bacterial slurries or sterile $\mathrm{ddH}_{2} \mathrm{O}$ and soil samples amended with ground autoclaved millet without Rhizoctonia served as controls. Three wheat seeds (cultivar Alpowa) were sown in each cone. Cones were arranged in a randomized complete block design in plastic racks and incubated in a growth chamber $16 / 8 \mathrm{~h}$ light/darkness at $16{ }^{\circ} \mathrm{C}$. Each cone received $10 \mathrm{ml}$ of water twice a week and diluted (1:3 [vol/ vol]) Hoagland's solution once a week. After 3 weeks, the seedlings were removed from the cones, the roots were washed free of soil, and the fresh weight, length of the shoots, and fresh weight of root were measured. Each treatment had 6 replicates, and the experiment was conducted three times.

\section{Statistical analysis}

Nonmetric multidimensional scaling (NMDS) and PERM ANOVA were performed on Bray-Curtis dissimilarities to assess the significance of planting cycles and $R$. solani AG8 infection on bacterial community structure using the metaMDS and "Adonis" functions of the vegan package (version 2.4.1) in $\mathrm{R}$ (version 3.6.3) [47]. ANOVA on $\log 2(1$ $+x$ )-transformed sequence counts of abundant $(>1 \%$ of total rarefied sequences) were used to examine significant differences in bacterial families among treatments $(p \leq 0.05)$ and heatmap was generated using ggplot2 package in $\mathrm{R}$ [48]. Bacterial richness and diversity metrics (Shannon's $[H]$ and inverse Simpson's $[1 / D]$ ) were estimated and compared among treatments using analysis of variance (ANOVA) followed by Tukey's honest significant difference (HSD) post hoc tests (Tukey's test). Differences in the relative abundances of bacterial genera in the rhizosphere soil between "good" (G) (the least wheat root disease) and "bad" (B) treatments (the worst wheat root disease) of successive planting cycles were assessed using DESeq2 analysis started with unrarefied OTU tables [49]. Briefly, unrarefied OTU tables were filtered to remove low abundance taxa $(<10$ total) and kept OTUs with normalized counts of $>5$ and that were present in three or more samples. Wald's test was used to contrast "good" and "bad" treatment in cycles 2 and 9. Genera were counted by OTUs and considered differentially abundant if they had a base mean $>50$, false discovery rate adjusted $p<0.1$, and estimated log2-fold change $>1$. Multiple comparisons were performed using Tukey test in JMP (SAS Institute, Cary, NC) to identify differentially abundant bacterial taxa that were impacted by planting cycles and $R$. solani AG8 infection. Significance was accepted at an alpha level of $\leq 0.05$.

\section{Results}

Soil bacterial community structure and composition

Severe wheat shoot stunting and root damage were observed in inoculated treatments compared with wheat growth without Rhizoctonia solani AG8 infection in the first planting cycle (cycle 1, Fig. 2, Additional file: Fig. S1). The severe wheat root damage and shoot stunting from AG8-infected plants were still obvious in the second cycle (cycle 2), compared with the controls (Fig. 2, 
Additional file: Fig. S2). However, starting from the fifth cycle (cycle 5), disease suppression on wheat was developed and there was stronger suppression in "good" treatment than in the "bad" treatment, and variation of disease symptoms among sub-replicates was observed (Additional file: Fig. S3). To reduce this variation of each sub-replicate, a total of nine such cycles were conducted. In the ninth planting cycle (cycle 9), both "good" and "bad" treatments showed clear disease suppression. The difference between "good" and "bad" treatments was reduced, with no significant difference in the fresh weight and length of the shoot at cycle 9 (Fig. 2, Additional file: Fig. S4), while the measurements were more uniform among the sub-replicates.

Soil microbiota were characterized from the rhizosphere soil of the R. solani AG8-infested (R) and noninfested controls (CK) in cycle 1, and the "good" (G) and "bad" (B) treatments and controls (CK) in cycles 2 and 9. A total of 2,674,677 sequences were obtained and represented by 7658 OTUs. Bacterial communities were dominated by phyla Proteobacteria $(50.52 \% \pm 0.75 \%$, mean $\pm \mathrm{SE}$, relative abundance among all samples), Bacteroidetes $(19.87 \% \pm 0.50 \%)$, and Actinobacteria $(9.54 \%$ $\pm 0.47 \%$ ) (Fig. 3a). The most abundant families included Chitinophagaceae $(9.02 \% \pm 0.54 \%)$, Sphingobacteriaceae $(7.23 \% \pm 0.29 \%)$, Oxalobacteraceae $(7.21 \% \pm 0.53 \%)$, Xanthomonadaceae $(7.17 \% \pm 0.56 \%)$, Pseudomonadaceae $(7.07 \% \pm 0.40 \%)$, and Enterobacteriaceae $(6.33 \% \pm 0.53 \%)$ (Fig. 3b).

\section{Bacterial community responses to multi-cycle plantings and Rhizoctonia solani AG8 infection}

Bacterial communities clustered clearly by planting cycles and $R$. solani AG8 infection (Fig. 4). The bacterial
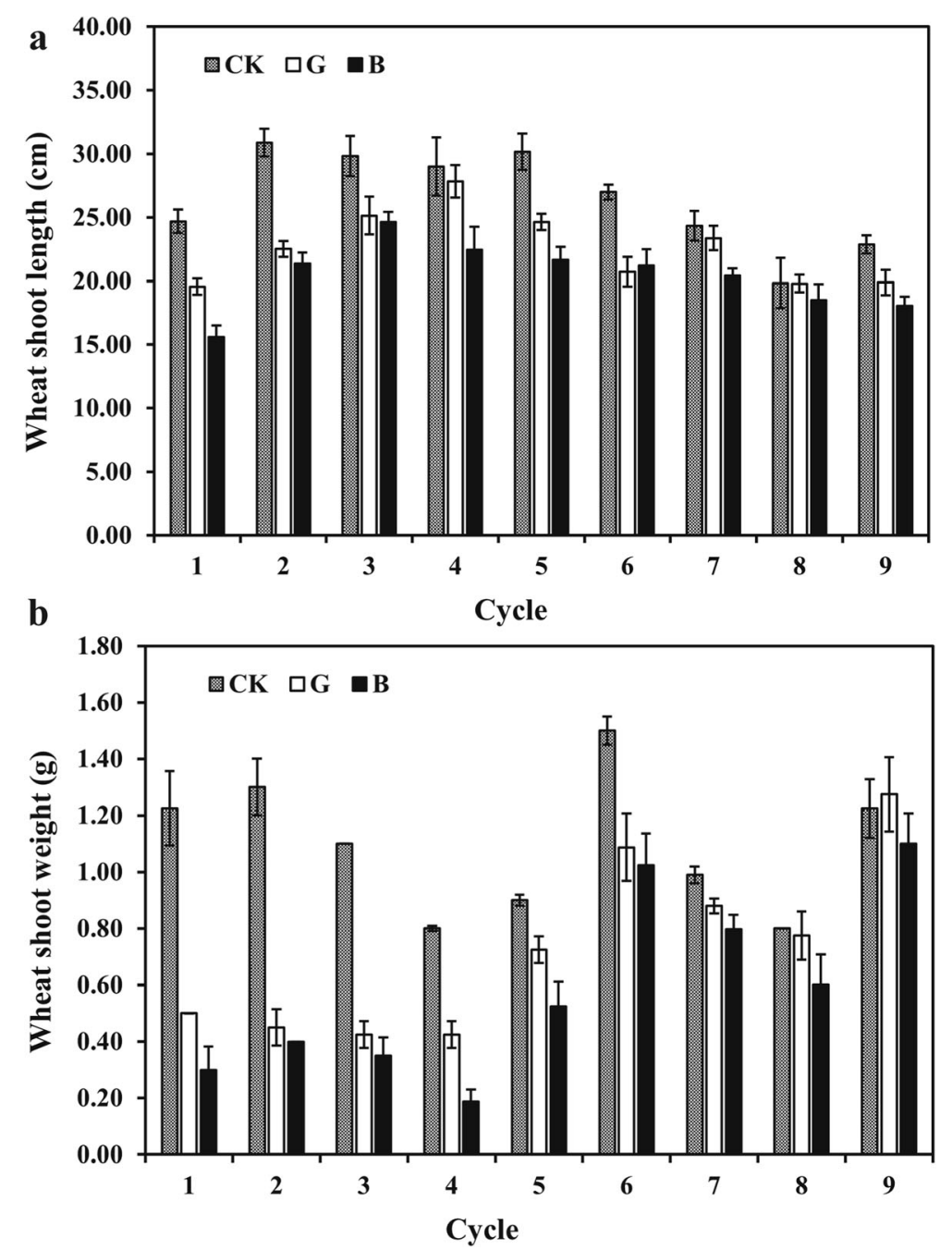

Fig. 2 The length and weight of fresh wheat shoot over wheat growth cycles. a The length of fresh wheat shoot. $\mathbf{b}$ The weight of fresh wheat shoot. CK: control plants without Rhizoctonia solani AG8 infection; B: plants with "bad" treatment (the worst wheat root disease); G: plants with "good" treatment (the least wheat root disease) 
communities from the AG8-infected wheat rhizosphere formed clusters distinct from those without AG8 infection, and AG8 infection further enhanced bacterial community separation among planting cycles. Interestingly, the bacterial communities from "good" (G) treatment (the rhizosphere with the least wheat root disease) gradually separated from those with "bad" (B) treatment (the worst wheat root disease) over successive planting cycles although there was still overlap in cycle 9 (Fig. 4).
Permutational multivariate analysis of variance (PERM ANOVA) supported the effect of multi-cycle plantings and AG8 infection on bacterial communities (Table 1).

As with bacterial community structure, bacterial richness and diversity were significantly reduced with increasing planting cycle $(p \leq 0.05$, Tukey's test). Moreover, the bacterial richness and diversity tended to be higher in control (CK) and AG8 infection (R) in cycle 1. However, the richness and diversity did not display

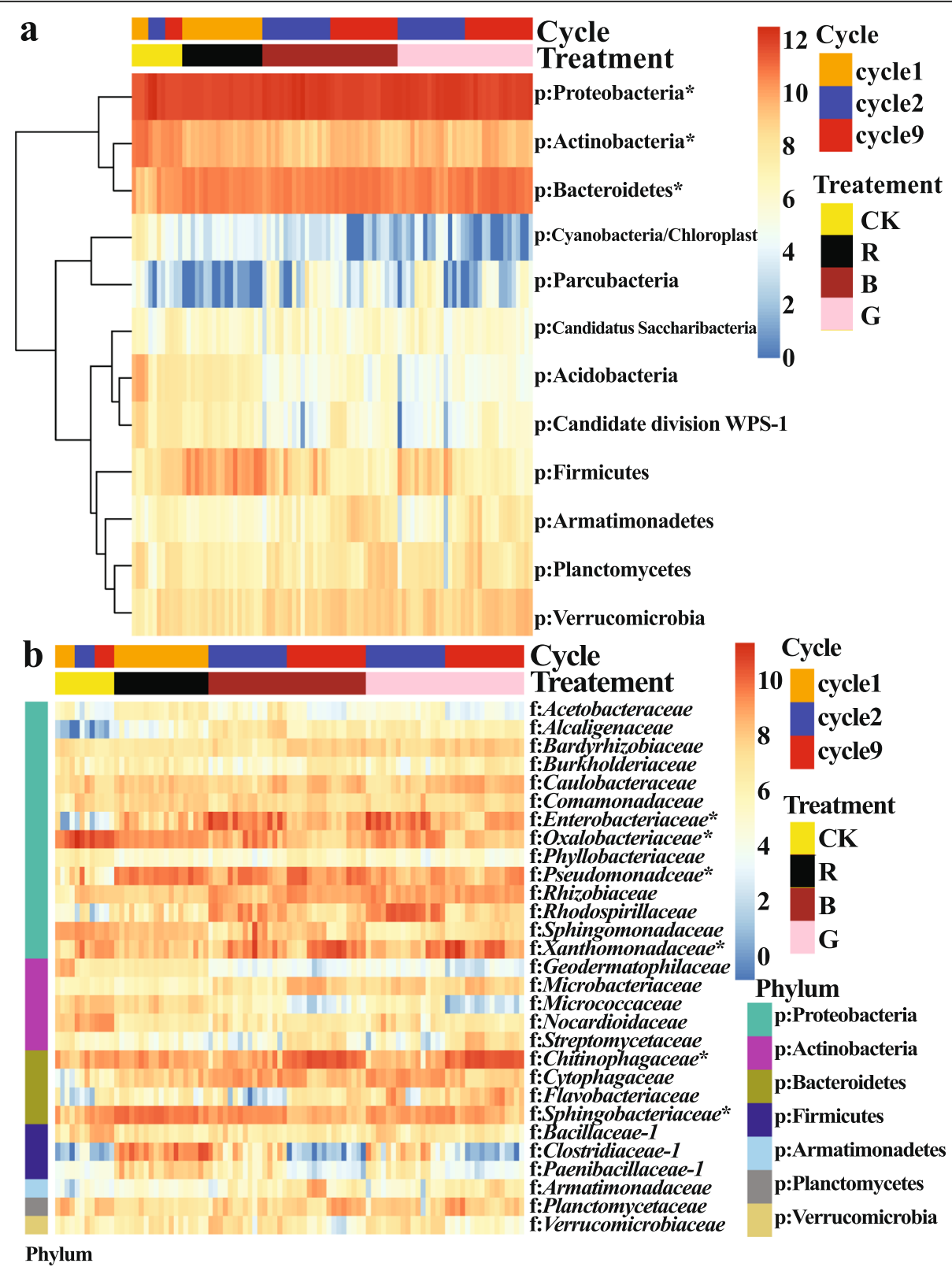

Fig. 3 Heatmap of abundant bacterial taxa (Log2 $(1+x)$-transformed sequence counts) which were clustered based on complete-linkage hierarchical clustering of Euclidean distances. a Heatmap of abundant phyla. $\mathbf{b}$ Heatmap of abundant families. CK: rhizosphere soil from control plants without $R$. solani AG8 infection; R: rhizosphere soil from plants infected with $R$. solani AG8 in cycle 1; B: rhizosphere soil from plants with "bad" treatment (the worst wheat root disease); G: rhizosphere soil from plants with "good" treatment (the least wheat root disease). The asterisk indicates the most abundant phylum or families 


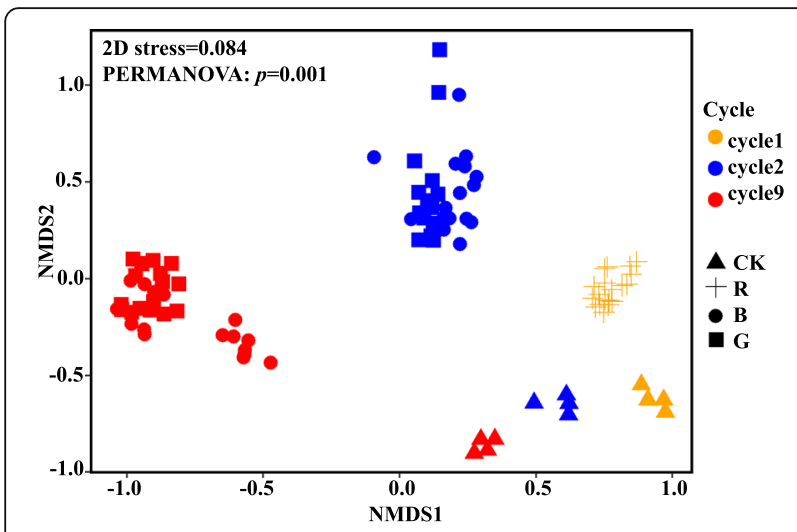

Fig. 4 NMDS of all samples colored by planting cycles and Rhizoctonia solani AG8 infection (stress $=0.084$ ). CK: rhizosphere soil from control plants without $R$. solani AG8 infection; R: rhizosphere soil from plants infected with $R$. solani AG8 in cycle 1; B: rhizosphere soil from plants with "bad" treatment (the worst wheat root disease); G: rhizosphere soil from plants with "good" treatment (the least wheat root disease)

significant differences between the "good" (G) and "bad" (B) treated bacterial communities (Table 2).

Phyla Acidobacteria, Actinobacteria, and Candidate division WPS-1 were more abundant in the wheat rhizosphere without $R$. solani AG8 infection than those with AG8 infection after nine planting cycles (Fig. 5a-c), while the phylum Bacteroidetes appeared to follow an opposite trend (Fig. $5 \mathrm{~d})$ ( $p \leq 0.05$, Tukey's test). Moreover, the planting cycles and $R$. solani AG8 infection were found to influence soil microbial communities at the family level (Fig. 6). For example, families Gaiellaceae, Planococcaceae, Cryptosporangiaceae, Oxalobacteraceae, Sphingomonadaceae, Bacillaceae_1, Phyllobacteriaceae, and Micrococcaceae were significantly more abundant from the wheat rhizosphere without AG8 infection (CK) than AG8infected wheat rhizosphere ( $\mathrm{R}, \mathrm{G}$, and B) ( $p \leq 0.05$, Tukey's test). Among them, the abundance of families Planococcaceae, Cryptosporangiaceae, and Bacillaceae_1 in the wheat rhizosphere without AG8 infection (CK) increased over cycles. In contrast, families Pseudomonadaceae, Rhizobiaceae, Rhodospirillaceae, and Cytophagaceae were more abundant in the rhizosphere of $R$. solani AG8-infected wheat. In addition, family Oxalobacteraceae in AG8- infected wheat dramatically decreased over planting cycles, whereas Xanthomonadaceae increased over planting cycles both with and without AG8 infection. Intriguingly, the rhizosphere soils of wheat from "good" (G) treatment were more enriched in Flavobacteriaceae than those from "bad" (B) treatment (Fig. 6).

After five successive plantings, wheat root damage and shoot stunting were relieved, indicating that disease suppression had developed. Similar results were reported in our previous greenhouse study and a few antagonistic bacteria were successfully isolated from the test samples [43]. Similarly, multi-cycle wheat plantings with $R$. solani AG8 infection recruited some microbial genera which have potential antagonistic activities against phytopathogens in this study (Fig. 7). For example, the genera Chitinophaga, Pseudomonas, Chryseobacterium, Flavobacterium, Serratia, and Rhodanobacter in the rhizosphere of AG8infected wheat were more abundant than those without AG8 infection, while genera Bacillus, Lysobacter, Duga$n e l l a$, and Mesorhizobium exhibited an opposite trend ( $p$ $\leq 0.05$, Tukey's test). Moreover, the abundance of Chitinophaga from AG8-infected wheat rhizosphere and Bacillus from the control samples significantly increased with the planting cycles. In addition, some genera of bacteria which are not known to have antagonistic functions also responded to successive wheat plantings and AG8 infection. Four genera (Dyadobacter, Kaistia, Herbiconiux, and Phenylobacterium) were found to be more abundant in AG8-infected wheat rhizosphere, whereas the abundance of six genera (Fimbriimonas, Sporosarcina, Methylobacterium, Ramlibacter, Bradyrhizobium, and Arthrobacter) increased in R. solani AG8 non-inoculated soils.

DESeq2 analysis identified some OTUs that were differentially abundant between the rhizosphere soils from "good" (G) treatment (the least wheat root disease) and "bad" (B) treatment (the worst wheat root disease) in both cycle 2 and cycle 9 (Fig. 8). Nineteen OTUs from cycle 2 samples and 15 OTUs from cycle 9 samples were influenced by "good" (G) and "bad" treatments, respectively. In cycle 2, 10 OTUs with relative abundances were enriched in wheat rhizospheres from "good" $(G)$ treatment, whereas nine OTUs were abundant in "bad" (B) treatment. In cycle 9, 11 OTUs were enriched in the

Table 1 PERMANOVA of impacts of plantings cycles and R. solani AG8 infection on bacterial communities

\begin{tabular}{|c|c|c|c|}
\hline Factor & $F$ value & $r^{2}$ & $p$ value $^{a}$ \\
\hline Cycle (cycle 1, 2, and 9) & 17.44 & 0.19 & $0.001 * * *$ \\
\hline Treatment (CK, R, B, and G) & 18.17 & 0.29 & $0.001 * * *$ \\
\hline Cycle (cycle 1, 2, and 9) $\times$ treatment $(C K, R, B$, and G) & 5.29 & 0.06 & $0.001 * * *$ \\
\hline
\end{tabular}

CK rhizosphere soil from control plants without $R$. solani AG8 infection, $R$ rhizosphere from plants infected with $R$. solani AG8 in the cycle 1, $B$ rhizosphere from plants with "bad" treatment (the worst wheat root disease), $G$ rhizosphere soil from plants with "good" treatment (the least wheat root disease). $P$ values are based on 1000 permutations

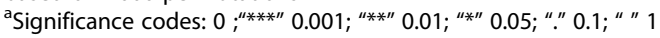


Table 2 Analysis of variance of richness and diversity indices

\begin{tabular}{lllll}
\hline Factors & & Shannon & Simpson & Richness \\
\hline Cycle & Cycle 1 & $6.56 \pm 0.06 \mathrm{a}$ & $245.38 \pm 27.44 \mathrm{a}$ & $2012.74 \pm 30.35 \mathrm{a}$ \\
& Cycle 2 & $5.61 \pm 0.06 \mathrm{~b}$ & $99.11 \pm 7.30 \mathrm{~b}$ & $1202.42 \pm 35.63 \mathrm{~b}$ \\
Treatment & Cycle 9 & $4.98 \pm 0.08 \mathrm{c}$ & $62.29 \pm 6.95 \mathrm{c}$ & $784.56 \pm 40.50 \mathrm{c}$ \\
& CK & $6.44 \pm 0.13 \mathrm{a}$ & $272.47 \pm 50.26 \mathrm{a}$ & $1716.67 \pm 105.01 \mathrm{a}$ \\
& R & $6.46 \pm 0.04 \mathrm{a}$ & $198.95 \pm 12.43 \mathrm{~b}$ & $1982.26 \pm 31.42 \mathrm{a}$ \\
& B & $5.05 \pm 0.08 \mathrm{~b}$ & $70.40 \pm 5.60 \mathrm{c}$ & $931.03 \pm 44.21 \mathrm{~b}$ \\
& G & $5.16 \pm 0.08 \mathrm{~b}$ & $65.05 \pm 4.80 \mathrm{c}$ & $901.16 \pm 47.92 \mathrm{~b}$ \\
\hline
\end{tabular}

$C K$ rhizosphere soil from control plants without $R$. solani AG8 infection, $R$ rhizosphere from plants infected with $R$. solani AG8 in cycle $1, B$ rhizosphere from plants with "bad" treatment (the worst wheat root disease), $G$ rhizosphere soil from plants with "good" treatment (the least wheat root disease). The values are means \pm standard error. Different letters indicate significant differences for indices ( $p \leq 0.05$, Tukey test). The statistical contrasts were performed separately among cycles and treatments

rhizospheres from the "good" (G) treatment and four were highly abundant in the "bad" (B) treatment. Notably, OTU 19 belonging to the genus Flavobacterium consistently increased in rhizospheres from "good" (G) treatment in both cycle 2 and cycle 9, while OTU17 (Sphingomonas) was more abundant in "bad" (B) treatment in both cycles. However, OTU1 (Azospirillum) and OTU18 (family Caulobacteraceae) showed an opposite pattern between "good" (G) and "bad" (B) treatments in both cycles, and most OTUs varied with planting cycles. Interestingly, the abundance of a group of plant growth-promoting (PGP) microbes, including
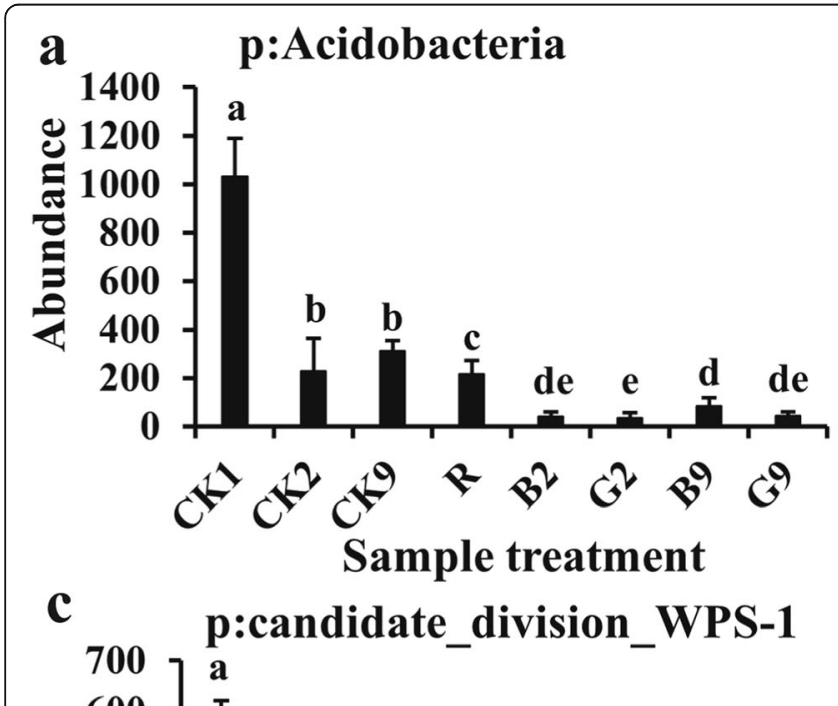

\section{b p:Actinobacteria}

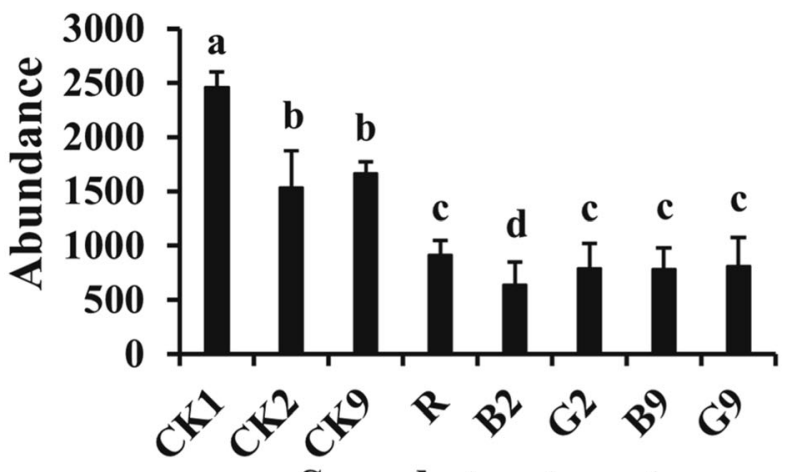

d

\section{Sample treatment}

\section{p:Bacteroidetes}

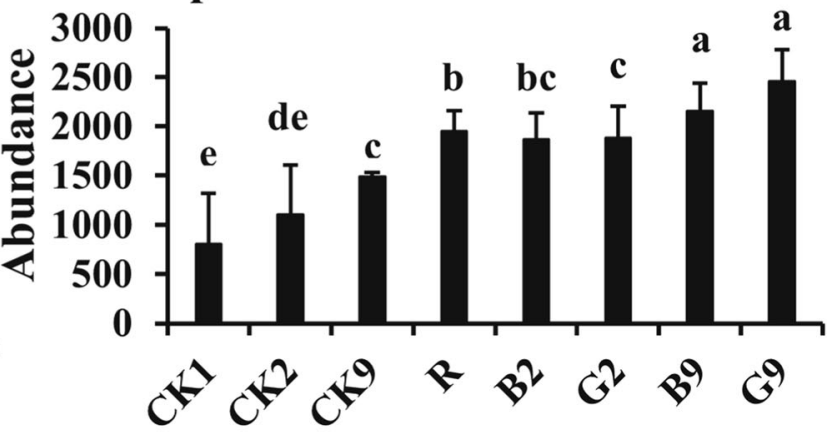

\section{Sample treatment}

Fig. 5 Bacterial phyla influenced by planting cycles and Rhizoctonia solani AG8 infection. CK1, CK2, and CK9: rhizosphere soil from control plants without $R$. solani AG8 infection in cycle 1, cycle 2, and cycle 9, respectively; R: rhizosphere soil from plants infected with $R$. solani AG8 in cycle 1; G2, G9: rhizosphere soil from plants with "good" treatment (the least wheat root disease) in cycle 2 and cycle 9, respectively; B2, B9: rhizosphere soil from plants with "bad" treatment (the worst wheat root disease) in cycle 2 and cycle 9 , respectively. The values are means \pm SE. Different letters indicate significant differences ( $p \leq 0.05$, Tukey's test) 


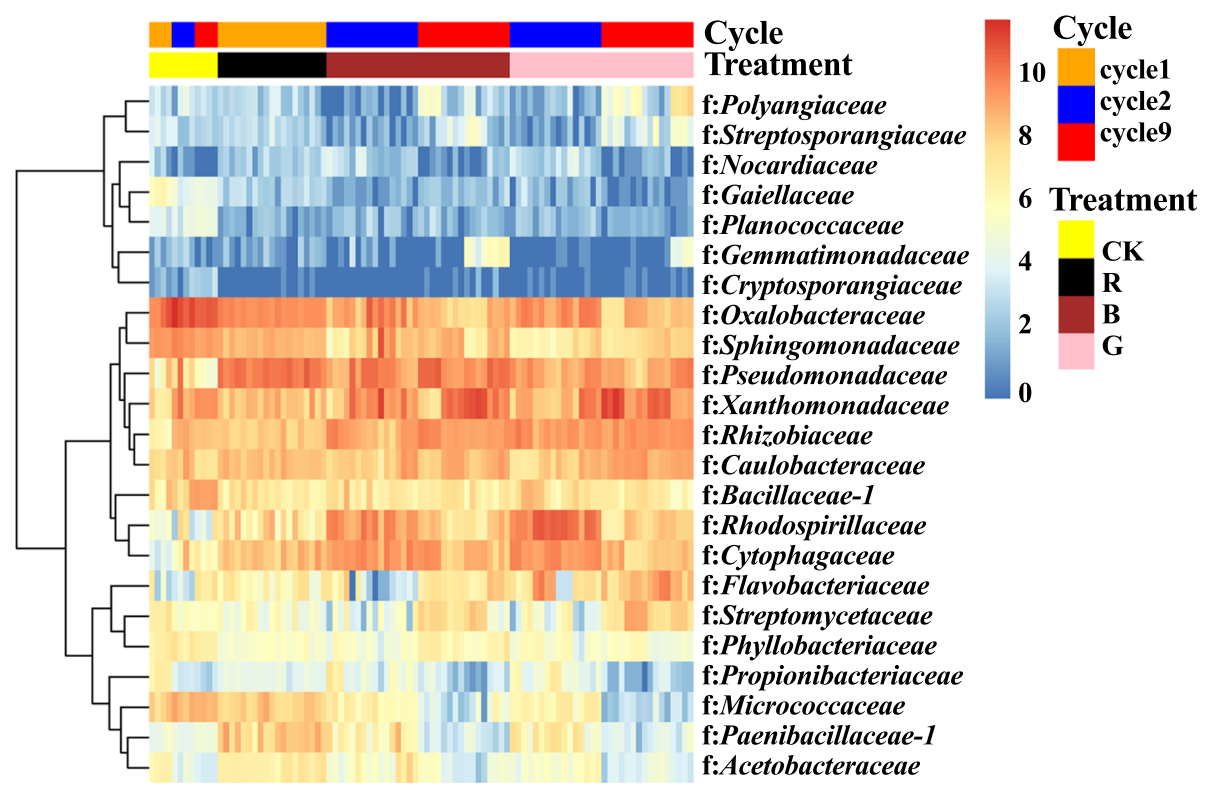

Fig. 6 Heatmap of bacterial families significantly influenced by planting cycles and Rhizoctonia solani AG8 infection with a $p$ value of $\leq 0.05$ based on ANOVA of (Log2 $(1+x)$-transformed sequence counts and clustered based on complete-linkage hierarchical clustering of Euclidean distances. Colored bars at the right-top of the graph presented the planting cycles and R. solani AG8 inoculation for each sample. CK: rhizosphere soil from control plants without $R$. solani AG8 infection; R: rhizosphere soil from plants infected with $R$. solani AG8 in cycle 1; B: rhizosphere soil from plants with "bad" treatment (the worst wheat root disease); G: rhizosphere soil from plants with "good" treatment (the least wheat root disease)

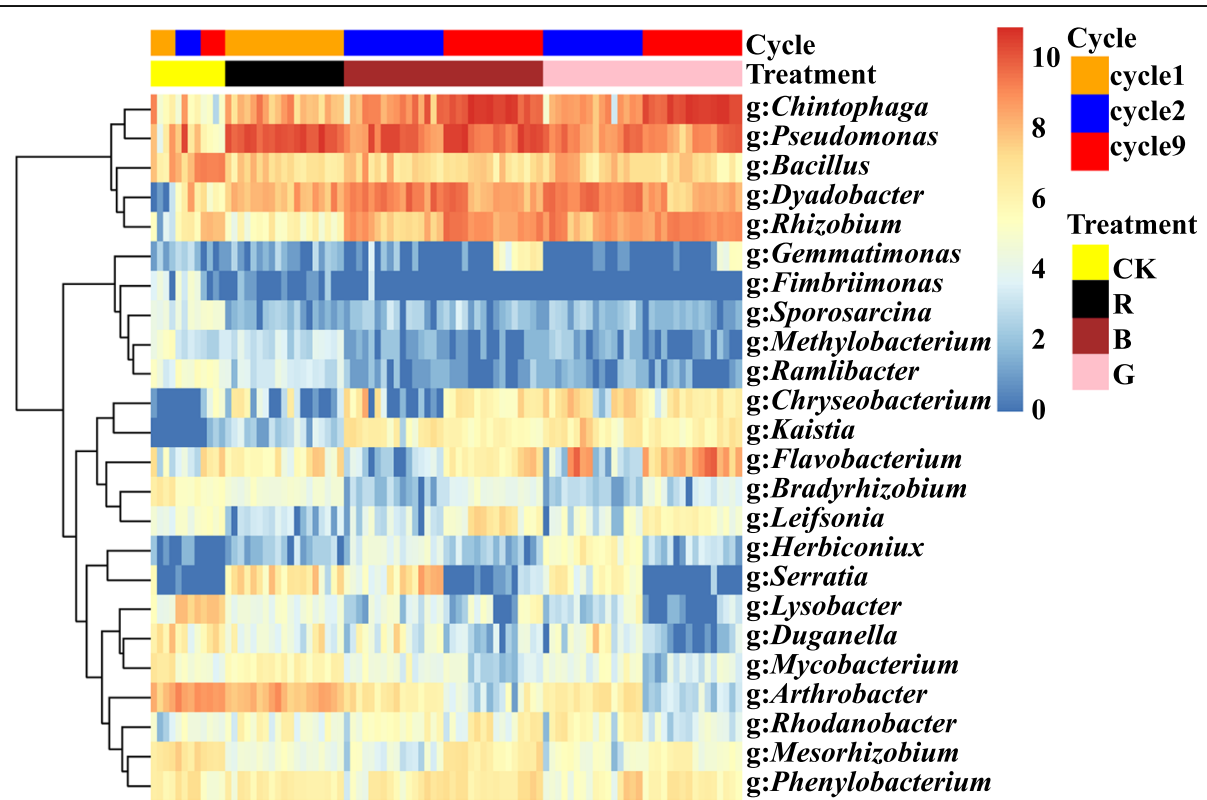

Fig. 7 Heatmap of bacterial genera significantly influenced by planting cycles and Rhizoctonia solani AG8 infection with a $p$ value of $\leq 0.05$ based on ANOVA of (Log2 $(1+x)$-transformed sequence counts and clustered based on complete-linkage hierarchical clustering of Euclidean distances. Colored bars at the right-top of the graph presented the planting cycles and R. solani AG8 inoculation for each sample. CK: rhizosphere soil from control plants without $R$. solani AG8 infection; R: rhizosphere soil from plants infected with $R$. solani AG8 in cycle 1; B: rhizosphere soil from plants with "bad" treatment (the worst wheat root disease); G: rhizosphere soil from plants with "good" treatment (the least wheat root disease) 


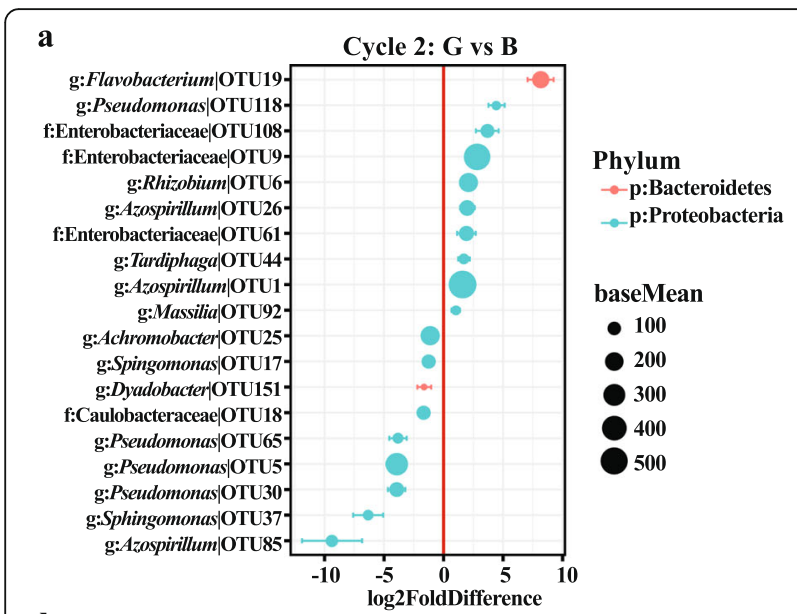

b

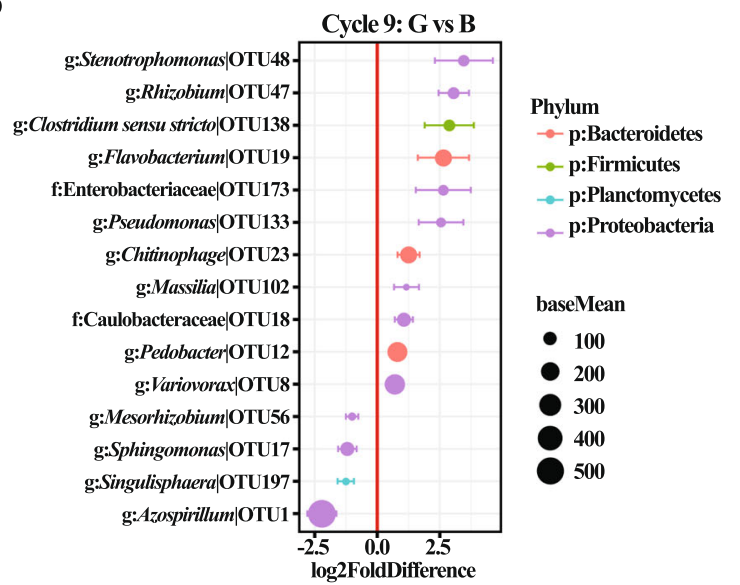

Fig. 8 Differentially abundant OTUs identified in the rhizosphere soil from plants between "good" treatment (the least wheat root disease) and "bad" treatment (the worst wheat root disease) in cycle 2 (a) and cycle 9 (b). Values on the $x$-axis presented the DESeq2-estimated log2-fold difference in the rhizosphere soil from plants between "good" treatment and "bad" treatment samples, where positive values indicate higher abundances in 'Good ' treatment and negative values indicate reduced abundance in "bad" treatment (FDR adjusted $p$-values of $<0.1$ were considered to be differentially abundant, Wald's test). Dots indicate OTUs, where the size of the dot is scaled by its mean abundance among all samples (base mean > 50) and its color represents the phylum to which that OTU belongs. The nearest taxonomy assignment is presented at left. Only OTUs with a mean abundance $>10$ and normalized counts $>5$ and present in at least 3 samples are presented

Rhizobium, Pedobacter, and Variovorax, increased in the rhizosphere from the "good" (G) treatment in cycle 9 (Fig. 8b). Together, these data highlighted that multicycle wheat plantings dramatically changed the structure of rhizosphere soil microbial communities, and $R$. solani AG8 application further drove these differences. Furthermore, some plant-beneficial microbial species were enriched with plant growth cycles that may induce suppression of AG8 and enhance plant growth.
Antifungal capabilities of bacteria in vitro

To confirm the ability of plants to recruit beneficial bacterial taxa, bacteria were isolated from rhizosphere soils collected from cycles 5, 6, 7, 8, and 9. In this study, a total of 47 bacteria were isolated and categorized into 35 species at a $97 \%$ similarity of sequence threshold (Additional file: Table S1). These bacteria were then tested in dual culture assays for their antagonism against soilborne pathogens, Rhizoctonia solani AG8, $R$. oryzae, and Pythium ultimum. Eleven of 35 bacterial species exhibited antagonistic activities to AG8 at different levels. These were Pantoea (OTU951), Pseudomonas (OTU163), Streptomyces (OTU22), Chryseobacterium (OTU993), Pseudomonas (OTU118), Pseudomonas (OTU245), Sphingomonas (OTU2657), Cupriavidus (OTU162), Asticcacaulis (OTU29), Rhodococcus (OTU854) (Fig. S5), and Janthinobacterium (OTU131) (Fig. 9a). Six bacterial species, belonging to the genera Pseudomonas (OTU163), Chryseobacterium (OTU993), Pseudomonas (OTU118), Pseudomonas (OTU245), Sphingomonas (OTU2657) (Fig. S6), and Janthinobacterium (OTU131) (Fig. 9a), displayed antagonisms against $R$. oryzae (Fig. 9a). Only one bacterial species, Janthinobacterium (OTU131), inhibited the growth of Pythium ultimum in $1 / 4$ TSA medium (Fig. 9a). Janthinobacterium (OTU131) was used for further study because it exhibited broad antagonistic activities to all three soilborne pathogens. Janthinobacterium is a gram-negative bacterium able to produce violacein, a dark purple-violet compound with antimicrobial properties [50] (Fig. S7). When the diluted rhizosphere soil slurries were plated on $1 / 4$ TSA medium, more dark-purple colonies were observed from the rhizosphere soil with "good" (G) treatment (the least wheat root disease) than those with "bad" (B) treatment (the worst wheat root disease) (Data not shown). This phenomenon was supported by our sequence data; Janthinobacterium (OTU131) were more abundant in wheat rhizospheres from "good" (G) treatment (relative abundance: $1.84 \pm 0.01 \%$, mean $\pm \mathrm{SE}$ ) than those from "bad" (B) treatment (relative abundance: $0.52 \pm 0.01 \%)$ in planting cycle 9. Furthermore, in dual culture assays, the percent inhibition of radial growth (PIRG) values for $R$. solani AG8, R. oryzae, and Pythium ultimum were $49.63 \% \pm 0.56 \%, 13.33 \% \pm 1.51 \%$, and $20.12 \% \pm 1.84 \%$, respectively (Table 3 ).

\section{Inhibitory effect of Janthinobacterium on Rhizoctonia solani AG8 in soil}

Janthinobacterium was further tested to determine its disease suppression activity against $R$. solani AG8 in soil in a greenhouse experiment. The same Lind soil was used, and wheat seeds were treated with the Janthinobacterium bacterial slurries (the optical density OD600 value of 1.0) before planting. After 3 weeks growth, 


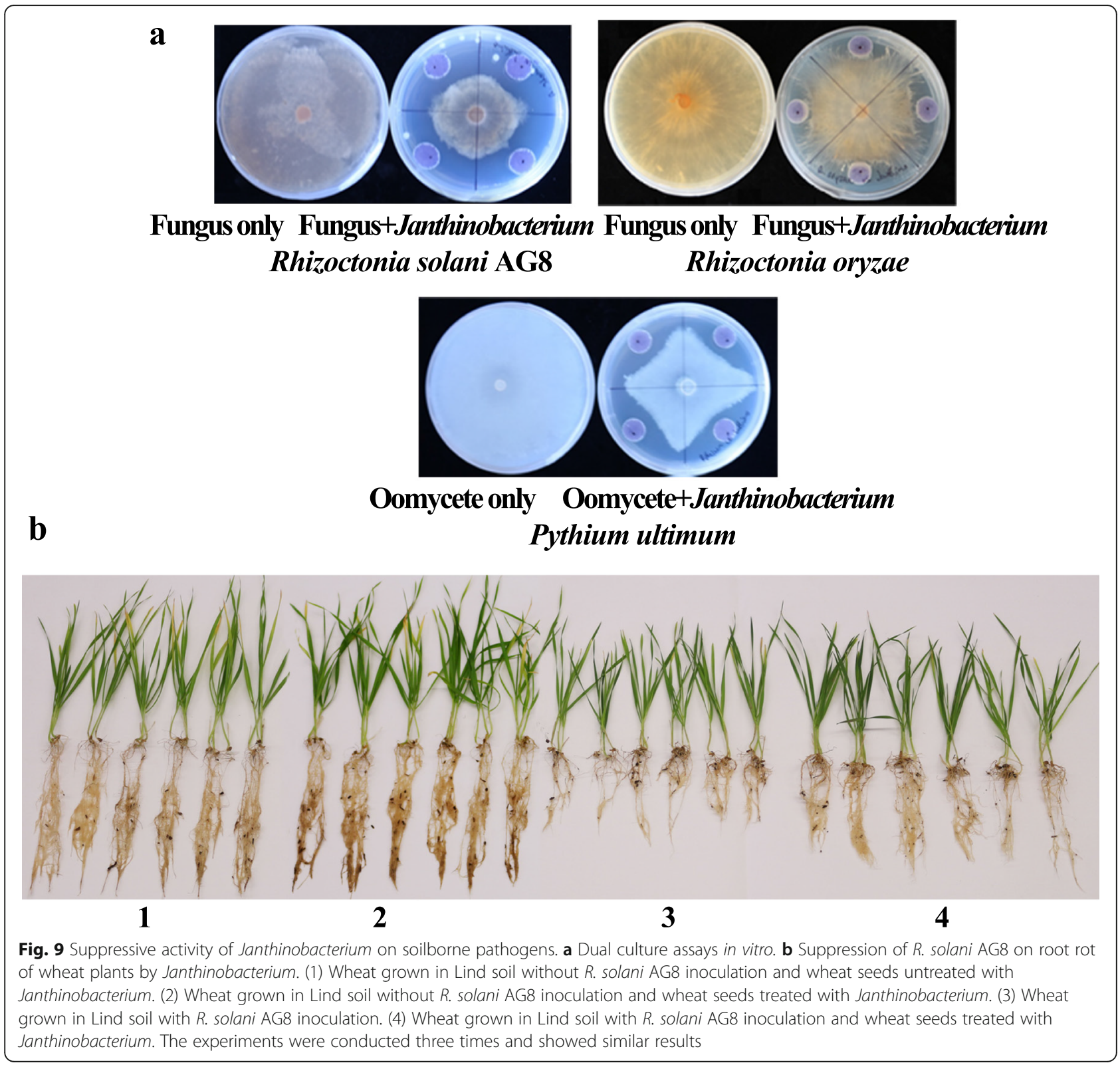

compared with the controls (plant seeds untreated/ treated with Janthinobacterium, but without AG8 infection), three-week-old wheat seedlings were stunted in all $R$. solani AG8-infested soils compared with noninfested, but grew marginally better following the

Table 3 Inhibition of radial growth of soilborne pathogens in dual culture by Janthinobacterium

\begin{tabular}{ll}
\hline Soilborne pathogens & \% inhibition of radial growth \\
\hline Pythium ultimum & $20.1 \pm 1.8$ \\
Rhizoctonia solani AG8 & $49.6 \pm 0.6$ \\
Rhizoctonia oryzae & $13.3 \pm 1.5$
\end{tabular}

The values are means \pm standard error of three replicates. The experiments were repeated three times with similar results (Additional file: Table S2)
Janthinobacterium bacterial treatment. The fresh weight of wheat roots treated with Janthinobacterium significantly increased compared with AG8 inoculation only, although it was still significantly less than the controls (Table 4 and Fig. 9b). The shoot fresh weight and length of wheat seedlings were similar in both AG8 inoculation only and AG8 with Janthinobacterium treatment, but less or shorter than in the controls.

\section{Discussion}

A growing body of research indicates host plants impact root-associated microbial communities [28, 35, 51, 52]. We conducted the multi-cycle plantings with infection by the fungal pathogen Rhizoctonia solani AG8 to reveal 
Table 4 The suppression activity of Janthinobaterium against Rhizoctonia solani AG8 in greenhouse assay

\begin{tabular}{llll}
\hline Treatment & Wheat root fresh weight $(\mathbf{g})$ & Wheat shoot fresh weight $(\mathbf{g})$ & Wheat shoot length $(\mathbf{c m})$ \\
\hline - AG8 - Janthinobacterium & $251.83 \pm 13.54 \mathrm{a}$ & $715.43 \pm 39.27 \mathrm{a}$ & $20.95 \pm 0.46 \mathrm{a}$ \\
- AG8 + seed treated with Janthinobacterium & $272.92 \pm 25.69 \mathrm{a}$ & $837.40 \pm 29.3 \mathrm{a}$ & $20.82 \pm 0.45 \mathrm{a}$ \\
+ AG8 only & $145.42 \pm 10.79 \mathrm{c}$ & $439.92 \pm 38.38 \mathrm{~b}$ & $16.08 \pm 0.32 \mathrm{~b}$ \\
+ AG8 + seed treated with Janthinobacterium & $197.48 \pm 12.65 \mathrm{~b}$ & $596.75 \pm 47.48 \mathrm{ab}$ & $17.04 \pm 0.32 \mathrm{~b}$ \\
\hline
\end{tabular}

"+": with, "-": without. The values are means \pm standard error of six replicates. The experiments were repeated three times with similar results (Additional file: Table S3). Different letters indicate significant differences ( $p \leq 0.05$, Tukey's test)

that successive plantings enhanced disease suppression on wheat and shaped the rhizosphere bacterial communities. Application of the pathogen AG8 further drove the differences of the wheat-associated bacterial communities. Moreover, the bacterial communities in the wheat rhizospheres from "good" (G) treatment (the least wheat root disease) gradually separated from those from "bad" (B) treatment (the worst wheat root disease) over the planting cycles. Most notably, some bacterial species were isolated from the wheat rhizospheres over multicycle growth and displayed antagonistic activities to soilborne fungal pathogens. Among them, a species of Janthinobacterium exhibited broad-spectrum antagonism against $R$. solani AG8, $R$. oryzae, and Pythium ultimum in a dual culture assay and against AG8 in soil. Overall, these findings suggest that repeated monocultures and AG8 infestation could change the root microbiome structure and recruit beneficial microbiota which promote plant growth and reduce soilborne pathogens, and eventually might induce disease-suppressive soils.

Multi-cycle wheat plantings accompanied by rhizosphere microbiota transfers reduced root rot disease caused by $R$. solani AG8 and the root disease suppression was enhanced over successive growth cycles. Soils suppressive to Rhizoctonia were similarly reported in our previous study [43] and in the agricultural fields in Australia and the Pacific Northwest in the USA [53-55]. Further studies of disease suppressive soil suggested that suppression resulted from the shifts in microbial community composition and activity, enhancing several groups of bacteria including Pantoea agglomerans, Exiguobacterium acetylicum, and Microbacteria [56]; Asaia spp. and Paenibacillus borealis [57]; and Flavobacterium, Chryseobacterium, and Chitinophaga [43]. In this study, some bacterial genera that have potential disease suppressive activities were significantly affected by the plant growth cycles. For example, bacteria within the genus Bacillus significantly increased with plant growth cycles without AG8 infection. It is well documented that Bacillus spp. secrete several metabolites not only to trigger plant growth but to inhibit pathogenic microbial growth in soil or kill pathogens through degrading the cell walls [58-60]. The abundance of Chitinophaga was significantly higher in AG8-infested wheat rhizosphere in cycle
9 than those in cycle 2 and cycle 1 (Fig. 7), which is consistent with our previous study [43]. In addition, bacterial species diversity and richness were observed to significantly decline with increasing growth cycle. This might be partially due to starting with cycle 2 , in which pasteurized soil was used, which kills or removes some harmful microorganisms compared with the native Lind soil in control and cycle 1. However, the same pasteurization treatment was used for the second cycle and following cycles, and the reduction of bacterial species diversity was still observed over the growth cycles. This could be due to the shifts of bacterial communities driven by the plant and AG8 to favor certain bacterial species over others, leading to reduced bacterial diversity and more plant-specific communities.

Disease suppressive soils typically develop after a disease outbreak [55, 61-64]. This phenomenon is often attributed to plants changing the structure of the microbial community and recruiting protective microbiota in the rhizosphere in response to pathogen attack by producing chemical compounds. In our multi-cycle wheat planting selection system, the soilborne fungal pathogen AG8 was inoculated into soil. The bacterial communities recruited to the AG8-infected rhizosphere were distinct from those without AG8 infection. AG8 infection also enhanced bacterial community separation during cycling indicating the pathogen application modified changes in microbial community composition driven by successive plantings. Similar changes were reported in other studies [64]. For instance, tomato plants challenged with the pathogen Ralstonia solanacearum revealed that the soil microbial abundances were changed through the plant root exudation in infected plants [65]. Barley plants challenged with Fusarium graminearum enriched the rhizosphere microbiome with potentially antifungal microbes [41]. There is increasing evidence that plants produce compounds to attract beneficial microbes or stimulate the expression of antifungal genes to react to pathogen infection. Therefore, plants can acclimate to biotic stress $[39,41,66]$.

Interestingly, $R$. solani AG8 infection increased the abundance of some genera that have suppressive or antagonistic functions, such as Chitinophaga, Pseudomonas, Chryseobacterium, Flavobacterium, Serratia, and 
Rhodanobacter. Similar results were reported in our previous study [43]: Chitinophaga, Flavobacterium, and Chryseobacterium were more abundant in the rhizosphere of diseased plants infected by $R$. solani AG8 than those of healthy plants. Moreover, some strains of Flavobacterium and Chryseobacterium produce antimicrobial compounds and stimulate plant immune systems and have been used as bioremediation agents [67]. Most recently, Nishioka et al. [68] recovered Flavobacterium species from the rhizosphere soils of the Allium plants that suppressed Fusarium wilt on cucumber seedlings and demonstrated that the Flavobacterium isolates inhibited the multiplication of the pathogen in soil. Flavobacterium was also found to be one of the most abundant bacterial genera present in the soil of banana fields in which Fusarium wilt decline had occurred [69]. The genus Serratia belongs to the family Enterobacteriaceae within the Gammaproteobacteria. Serratia plymuthica is a ubiquitous gram-negative bacterium, most frequently associated with plants and used as a broad-spectrum biocontrol agent because it produces antimicrobial compounds [70-72] and was successfully developed as a commercial product called Rhizostar (produced by Enema GmbH Raisdorf, Germany). Recently Serratia marcescens was found to produce several hydrolytic enzymes and showed antagonistic activity against eight fungal pathogens of tea [73]. In contrast, genera Bacillus, Duganella, and Lysobacter were more highly abundant in the rhizosphere soil without AG8 infection. Some strains of Bacillus can suppress pathogen-derived microbe-associated molecular patterns (MAMPs)-triggered root immune responses and protect Arabidopsis against pathogens [74]. In a previous field study [43] Duganella was more abundant in diseased plant rhizospheres, indicating Duganella may have different behavior in specific conditions. Lysobacter is a chitinolytic bacterium and has potential antagonistic activity against Rhizoctonia and nematodes [75-77]. Collectively, the data indicate that upon pathogen attack, pathogenstressed plants may undergo changes in metabolic pathways and modulate the chemical composition of their rhizospheres, which recruit beneficial and antagonistic bacterial communities. The accumulation of antagonistic microbes can protect plants against the pathogens that initiated the recruitment. In addition, the abundance of other genera was also changed by AG8 infection in this study. Most of them are non-antagonistic bacteria or their biological functions are still unknown. Interestingly, Fujiwara et al. [78] reported that a community of seven non-antagonistic bacterial strains, including one Kaistia strain, suppressed the fungal phytopathogen $\mathrm{Fu}$ sarium oxysporum and morphological observations showed the formation of swollen F. oxysporum cells in the presence of these bacterial pairs. It demonstrated that complex interactions among apparently nonantagonistic bacteria can result in antagonism against pathogens. Thus, these uncharacterized emergent functions of bacterial consortia may also contribute to suppression activities but require further investigation. Taken together, our results provide further evidence that under the pressure of pathogen attack, plants can enrich beneficial microorganisms to suppress pathogens in the rhizosphere.

In our multi-cycle selection system, wheat seedlings with roots showing relatively more or less disease to $R$. solani AG8 were screened from each cycle and used as rhizosphere inoculants for the following cycle, thus forming the two groups, "good" (G) (the least wheat root disease) treatment and "bad" (B) (the worst wheat root disease) treatment. In the first two cycles, wheat displayed severe stunting. Starting from cycle 3, suppressiveness to AG8 gradually developed and was notable by cycle 5 , but the disease severity was still variable among four replicates from "good" or "bad" treatments. To achieve uniform disease symptoms among replicates, the planting was continued and by the 9th cycle all wheat plants of two treatments were tolerant to AG8 infection, but the "good" treatment showed slightly less disease symptoms than the "bad" treatment. Consistent with the disease phenotype, sequence analysis found that the microbial communities separated gradually over the growth cycles. The different quantities of diseased roots likely affect the microbial community composition, but other factors may also contribute. Although care was taken to water the plant containers equally, those with more severe root disease had reduced root systems and typically retained more moisture towards the end of the cycles. Thus, water content may influence soil microbiomes and the development of suppressive soils, something which should be addressed further. Furthermore, DESeq2 analysis found that some OTUs were differentially abundant in the rhizosphere soil between "good" (G) and "bad" (B) treatment in both cycle 2 and cycle 9 . Interestingly, the "good" treatment in cycles 2 and 9 was highly enriched the antagonistic microbe OTU 19 belonged to genera Flavobacterium [68]. In addition, a group of plant growth-promoting (PGP) microbes, including Rhizobium, Pedobacter, and Variovorax, were highly abundant in the rhizosphere soil from "good" (G) treatment in cycle 9. PGP microbes have shown potential to promote plant growth at different stages via a wide variety of mechanisms [79]. For example, Rhizobium is a gramnegative soil bacterium and promotes plant growth through establishing nitrogen-fixing symbiosis with leguminous plants and increasing soil fertility [80]. Another PGP microbe, Pedobacter is also capable of colonizing roots of many crops, such as oilseed rape, potato, and strawberry, and could be used as a biofertilizer [81-83]. 
Variovorax is a metabolically diverse genus of plant growth-promoting rhizobacteria which belongs to the family Comamonadaceae. Variovorax sp. promoted plant growth via producing plant growth substances and enzymes such as siderophores and ACC deaminase [84]. These results suggest that both antagonistic and PGP microbes might contribute to the improvement of wheat growth and tolerance to AG8. It is widely accepted that root exudates play a crucial role in the establishment of the root microbiome $[85,86]$ and different root exudates are thought to secrete chemical compounds to select specific microbial populations. In our study, although the same wheat cultivar was used, continuous screening of wheat with more tolerance or susceptibility to AG8 might change the components or amounts of chemical compounds or root signals which attract favorite microorganisms [33, 87]. Further efforts to analyze the root exudate composition of each cycle may greatly improve our understanding of the role of plants on the changes of microbial communities and elucidate the mechanisms underlying the recruitment of antagonistic bacteria by plant, and eventually lead to the development of ecofriendly soilborne pathogens management strategies.

In vitro bacterial isolation and antifungal capability testing found that eleven of 35 bacterial species inhibited the growth of $R$. solani AG8. Six of them suppressed $R$. oryzae and only one for Pythium ultimum. Testing further indicated that AG8 infection is a major driver for the colonization of those antagonistic isolates. Most of them, such as Pseudomonas, Streptomyces, and Chryseobacterium, have been well-documented as pathogen suppressive [43, 52, 61]. Interestingly, a Janthinobacterium produces a dark-purple compound, violacein [88]. More dark-purple colonies were observed in the rhizosphere from "good" (G) treatment (the least disease rhizosphere soil) than those from "bad" (B) treatment (the worst disease rhizosphere soil), indicating Janthinobacterium was more highly associated with rhizospheres of plants more tolerant to AG8. Janthinobacterium is a gram-negative aerobic bacterium, which belongs to the family Oxalobacteraceae of the Class Betaproteobacteria, and commonly exists in soil and aquatic habitats. As a secondary metabolite, violacein has been reported to have antifungal effects [89, 90]. However, Haack et al. [91] revealed that violacein was not the primary cause of the fungal growth inhibition by expressing violacein encoded gene vioABCDE in $E$. coli which had no significant inhibition on Fusarium graminearum growth and further observed that the fungal growth inhibition was independent of the amount of violacein. Our antifungal capabilities test showed that Janthinobacterium has a broad-spectrum antagonism against soilborne pathogens $R$. solani AG8, $R$. oryzae, and Pythium ultimum. Further greenhouse assays discovered that Janthinobacterium has antagonistic activity against AG8 in soil. Microbial communities have many potential applications in agriculture and medicine, such as pathogen suppression and environmental remediation. With more antagonistic and plant growthpromoting (PGP) microbes being discovered and isolated, synthetic microbial communities might provide plants with stronger disease resistance and growth promotion than single species, thus become more powerful biotechnological tools to improve the sustainability of agro-ecosystems [92]. Our results will provide valuable resources for the development and testing of synthetic microbial consortia in the future.

\section{Supplementary Information}

The online version contains supplementary material available at https://doi. org/10.1186/s40168-020-00997-5.

Additional file 1. Methodological Supplement for the V1-V3 hypervariable region of 165 rRNA gene was amplified by PCR.

Additional file 2: Table S1. Bacteria isolated from rhizosphere soil in this study.

Additional file 3: Table S2. Inhibition of radial growth of soilborne pathogens in dual culture by Janthinobacterium (replicates 2 and 3).

Additional file 4: Table S3. The suppression activity of Janthinobaterium against Rhizoctonia solani AG8 in greenhouse assay (replicates 2 and 3).

Additional file 5: Figure S1. The phenotype of wheat grown in Lind soil in the growth chamber after the cycle 1. CK: control without Rhizoctonia solani AG8 infection.

Additional file 6: Figure S2. The phenotype of wheat grown in pasteurized Lind soil in greenhouse after cycle 2. CK: control plants without Rhizoctonia solani AG8 infection; G: plants with 'Good' treatment (the least wheat root disease); B: plants with 'Bad' treatment (the worst wheat root disease).

Additional file 7: Figure S3. The phenotype of wheat grown in pasteurized Lind soil in greenhouse after cycle 5. CK: control plants without Rhizoctonia solani AG8 infection; G: plants with 'Good' treatment (the least wheat root disease); B: plants with 'Bad' treatment (the worst wheat root disease).

Additional file 8: Figure S4. The phenotype of wheat grown in pasteurized Lind soil in greenhouse after cycle 9. CK: control plants without Rhizoctonia solani AG8 infection; G: plants with 'Good' treatment (the least wheat root disease); B: plants with 'Bad' treatment (the worst wheat root disease).

Additional file 9: Figure S5. Dual culture assays in vitro for inhibition of growth of Rhizoctonia solani AG8 by bacteria isolates on 1/4 TSA medium.

Additional file 10: Figure S6. Dual culture assays in vitro for inhibition of growth of Rhizoctonia oryzae by bacteria isolates on 1/4 TSA medium.

Additional file 11: Figure S7. Violacein produced by Janthinobacterium on TSA medium.

\footnotetext{
Acknowledgements

This work was supported by Washington State University, the USDA Agricultural Research Service, and Columbia Basin Agricultural Research Center at Oregon State University. We thank Jade Ermita and Ron Sloot for soil collection and preparation, Cuiling Gao for soil DNA extraction, and Fengjuan Lv for bacteria isolation.
}

Authors' contributions

CY and SHH conceived and designed research; $C Y$ and JMCV performed research; $\mathrm{CY}$ and DCS analyzed the data; $\mathrm{CY}, \mathrm{SHH}, \mathrm{CH}$, and TP contributed 
reagents/materials/analysis tools; $\mathrm{CY}, \mathrm{DCS}, \mathrm{CH}, \mathrm{SHH}$, and TP wrote the paper. The author(s) read and approved the final manuscript.

\section{Funding}

This work was supported by Washington State University, the USDA Agricultural Research Service, and Columbia Basin Agricultural Research Center at Oregon State University

\section{Availability of data and materials}

The raw sequence data was deposited in the SRA of the NCBI (https://www ncbi.nlm.nih.gov/sra) under accession number PRJNA578725. The datasets during and/or analyzed during the current study available from the corresponding author on reasonable request.

\section{Declarations}

\section{Ethics approval and consent to participate}

Not applicable

\section{Consent for publication}

Not applicable

\section{Competing interests}

The authors declare that they have no competing interests

\section{Author details}

'Department of Plant Pathology, Washington State University, Pullman, WA 99164-6430, USA. ${ }^{2}$ USDA-ARS, Wheat Health, Genetics and Quality Research Unit, Washington State University, Pullman, WA 99164-6430, USA. ${ }^{3}$ Columbia Basin Agricultural Research Center, Oregon State University, Adams, OR 97810, USA.

\section{Received: 20 August 2020 Accepted: 29 December 2020} Published online: 09 April 2021

\section{References}

1. Bulgarelli D, Schlaeppi K, Spaepen S, van Themaat EVL, Schulze-Lefert P. Structure and functions of the bacterial microbiota of plants. Annu Rev Plant Biol. 2013;64(1):807-38. https://doi.org/10.1146/annurev-arplant050312-120106.

2. Jacoby R, Peukert M, Succurro A, Koprivova A, Kopriva S. The role of soil microorganisms in plant mineral nutrition-current knowledge and future directions. Front Plant Sci. 2017;8:1617. https://doi.org/10.3389/fpls.2017.01 617.

3. Richardson AE, Barea JM, Mcneill AM, Prigent-Combaret C. Acquisition of phosphorus and nitrogen in the rhizosphere and plant growth promotion by microorganisms. Plant Soil. 2009:321(1-2):305-39. https://doi.org/10.1007/ s11104-009-9895-2.

4. Etesami H, Hosseini HM, Alikhani HA, Mohammadi L. Bacterial biosynthesis of 1-aminocyclopropane1-carboxylate (ACC) deaminase and indole-3-acetic acid (IAA) as endophytic preferential selection traits by rice plants seedlings. J Plant Growth Regul. 2014;33(3):654-70. https://doi.org/10.1007/s00344014-9415-3.

5. $\mathrm{Xu} \mathrm{L}, \mathrm{Xu}$ W, Jiang $Y$, Hu F, Li H. Effects of interactions of auxin-producing bacteria and bacterial-feeding nematodes on regulation of peanut growths. PLoS One. 2015;10(4):e0124361. https://doi.org/10.1371/journal.pone.01243 61.

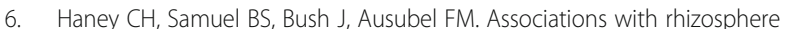
bacteria can confer an adaptive advantage to plants. Nat Plants. 2015;1 (6): 15051. https://doi.org/10.1038/nplants.2015.51.

7. Rolli E, Marasco R, Vigani G, Ettoumi B, Mapelli F, Deangelis ML, et al. Improved plant resistance to drought is promoted by the root-associated microbiome as a water stress-dependent trait. Environ Microbiol. 2015;17(2): 316-31. https://doi.org/10.1111/1462-2920.12439.

8. Mendes R, Kruijt M. deBruijn I, Dekkers E, van der Voort M, Schneider JHM, et al. Deciphering the rhizosphere microbiome for disease-suppressive bacteria. Science. 2011;332(6033):1097-100. https://doi.org/10.1126/ science. 1203980

9. Mendes R, Garbeva P, Raaijmakers JM. The rhizosphere microbiome: significance of plant beneficial, plant pathogenic, and human pathogenic microorganisms. FEMS Microbiol Rev. 2013;37(5):634-63. https://doi.org/1 $0.1111 / 1574-6976.12028$

10. Pozo MJ, Azcon-Aguilar C. Unraveling mycorrhiza-induced resistance. Curr Opin Plant Biol. 2017:10:393-8.

11. Ritpitakphong U, Falquet L, Vimoltust A, Berger A, Metraux JP, L'Haridon F. The microbiome of the leaf surface of Arabidopsis protects against a fungal pathogen. New Phytol. 2016;210(3):1033-43. https://doi.org/10.1111/nph.13808.

12. Bakker PA, Doornbos RF, Zamioudis C, Berendsen RL, Pieterse CM. Induced systemic resistance and the rhizosphere microbiome. Plant Pathol J. 2013; 29(2):136-43. https://doi.org/10.5423/PPJ.SI.07.2012.0111.

13. Lu T, Ke M, Lavoie M, Jin Y, Fan X, Zhang Z, et al. Rhizosphere microorganisms can influence the timing of plant flowering. Microbiome. 2018;6:1-12.

14. Agler MT, Ruhe J, Kroll S, Morhenn C, Kim ST, Weigel D, et al. Microbial hub taxa link host and abiotic factors to plant microbiome variation. PLoS Biol. 2016;14(1):e1002352. https://doi.org/10.1371/journal.pbio.1002352.

15. Reinhold-Hurek B, Bunger W, Burbano CS, Sabale M, Hurek T. Roots shaping their microbiome: global hotspots for microbial activity. Annu Rev Phytopathol. 2015;53(1):403-24. https://doi.org/10.1146/annurev-phyto-082 712-102342

16. Raaijmakers JM, Mazzola M. Soil immune responses. Science. 2016:352(6292): 1392-3. https://doi.org/10.1126/science.aaf3252.

17. Yu K, Pieterse CMJ, Bakker PAHM, Berendsen RL. Beneficial microbes going underground of root immunity. Plant Cell Environ. 2019;42(10):2860-70. https://doi.org/10.1111/pce.13632.

18. Berg M, Koskella B. Nutrient- and dose-dependent microbiome-mediated protection against a plant pathogen. Curr Biol. 2018;28(15):2487-92 e3. https://doi.org/10.1016/j.cub.2018.05.085.

19. Schlaeppi K, Dombrowski N, Oter RG, Van Themaat EVL, Schulze-Lefert P. Quantitative divergence of the bacterial root microbiota in Arabidopsis thaliana relatives. Proc Natl Acad Sci U S A. 2014;111(2):585-92. https://doi. org/10.1073/pnas.1321597111.

20. Zgadzaj R, Garrido-Oter R, Jensen DB, Koprivova A, Schulze-Lefert P, Radutoiu S. Root nodule symbiosis in Lotus japonicus drives the establishment of distinctive rhizosphere, root, and nodule bacterial communities. Proc Natl Acad Sci U S A. 2016;113(49):E7996-8005. https:// doi.org/10.1073/pnas.1616564113.

21. Bulgarelli D, Garrido-Oter R, Münch PC, Weiman A, Dröge J, Pan Y, et al. Structure and function of the bacterial root microbiota in wild and domesticated barley. Cell Host Microbe. 2015;17(3):392-403. https://doi. org/10.1016/j.chom.2015.01.011.

22. Kawasaki A, Donn S, Ryan PR, Mathesius U, Devilla R, Jones A, et al. Microbiome and exudates of the root and rhizosphere of Brachypodium distachyon, a model for wheat. PLoS One. 2016;11(10):e0164533. https://doi. org/10.1371/journal.pone.0164533.

23. Peiffer JA, Spor A, Koren O, Jin Z, Tringe SG, Dangl JL, et al. Diversity and heritability of the maize rhizosphere microbiome under field conditions. Proc Natl Acad Sci U S A. 2013;110(16):6548-53. https://doi.org/10.1073/pna S.1302837110.

24. Yao H, Wu F. Soil microbial community structure in cucumber rhizosphere of different resistance cultivars to fusarium wilt. FEMS Microbio Ecol. 2010; 72(3):456-63. https://doi.org/10.1111/j.1574-6941.2010.00859.x.

25. Mahoney AK, Yin C, Hulbert SH. Community structure, species variation, and potential functions of rhizosphere-associated bacteria of different winter wheat (Triticum aestivum) cultivars. Front Plant Sci. 2017:8:132.

26. Petrović $B$, Đurić $S$, Vasić $M$, Tunguz V, Pokluda R. Effect of bean cultivars on soil microorganisms. Acta Univ Agric et Silvic Mendelianae Brun. 2018;66(1): 155-60. https://doi.org/10.11118/actaun201866010155.

27. Lundberg DS, Lebeis SL, Paredes SH, Yourstone S, Gehring J, Malfatti S, et al. Defining the core Arabidopsis thaliana root microbiome. Nature. 2012; 488(7409):86-90. https://doi.org/10.1038/nature11237.

28. Tkacz A, Cheema J, Chandra G, Grant A, Poole PS. Stability and succession of the rhizosphere microbiota depends upon plant type and soil composition. ISME J. 2015;9(11):2349-59. https:/doi.org/10.1038/ismej.2015.41.

29. Bodenhausen N, Bortfeld-Miller M, Ackermann M, Vorholt JA. A synthetic community approach reveals plant genotypes affecting the phyllosphere microbiota. PLoS Genet. 2014;10(4):e1004283. https://doi.org/10.1371/journa l.pgen.1004283.

30. Chaparro JM, Badri DV, Vivanco JM. Rhizosphere microbiome assemblage is affected by plant development. ISME J. 2014:8(4):790-803. https://doi.org/1 0.1038/ismej.2013.196 
31. Rudrappa T, Czymmek KJ, Pare PW, Bais HP. Root-secreted malic acid recruits beneficial soil bacteria. Plant Physiol. 2008;148(3):1547-56. https:// doi.org/10.1104/pp.108.127613.

32. Broeckling CD, Broz AK, Bergelson J, Manter DK, Vivanco JM. Root exudates regulate soil fungal community composition and diversity. Appl Environ Microbiol. 2008;74(3):738-44. https://doi.org/10.1128/AEM.02188-07.

33. Lareen A, Burton F, Schäfer P. Plant root-microbe communication in shaping root microbiomes. Plant Mol Biol. 2016;90(6):575-87. https://doi. org/10.1007/s11103-015-0417-8

34. Vannier N, Agler M, Hacquard S. Microbiota-mediated disease resistance in plants. PLoS Pathog. 2019;15(6):1-7.

35. Panke-Buisse K, Poole AC, Goodrich JK, Ley RE, Kao-Kniffin J. Selection on soil microbiomes reveals reproducible impacts on plant function. ISME J. 2015;9(4):980-9. https://doi.org/10.1038/ismej.2014.196.

36. Trivedi P, He Z, Van N, Joy D, Albrigo G, Zhou J, et al. Huanglongbing alters the structure and functional diversity of microbial communities associated with citrus rhizosphere. ISME J. 2012;6(2):363-83. https://doi.org/10.1038/ ismej.2011.100.

37. Xue C, Penton CR, Shen Z, Zhang R, Huang Q, Li R, et al. Manipulating the banana rhizosphere microbiome for biological control of Panama disease. Sci Rep. 2015;5(1):11124. https://doi.org/10.1038/srep11124.

38. Jousset A, Becker J, Chatterjee S, Karlovsky P, Scheu S, Eisenhauer N. Biodiversity and species identity shape the antifungal activity of bacterial communities. Ecology. 2014;95(5):1184-90. https://doi.org/10.1890/13-121 5.1.

39. Jousset A, Rochat L, Lanoue A, Bonkowski M, Keel C, Scheu S. Plants respond to pathogen infection by enhancing the antifungal gene expression of root-associated bacteria. Mol Plant-Microbe Interact. 2011; 24(3):352-8. https://doi.org/10.1094/MPMI-09-10-0208.

40. Poudel R, Jumpponen A, Schlatter DC, Paulitz TC, Gardener BBM, Kinkel LL, et al. Microbiome networks: a systems framework for identifying candidate microbial assemblages for disease management. Phytopathology. 2016; 106(10):1083-96. https://doi.org/10.1094/PHYTO-02-16-0058-FI.

41. Dudenhöffer JH, Scheu S, Jousset A. Systemic enrichment of antifungal traits in the rhizosphere microbiome after pathogen attack. J Ecol. 2016; 104(6):1566-75. https://doi.org/10.1111/1365-2745.12626.

42. Sharratt B, Schillinger WF. Soil characteristics and wind erosion potential of wheat-oilseed-fallow cropping systems. Soil Sci Soc Am J. 2016;80(3):704-10. https://doi.org/10.2136/sssaj2015.12.0427.

43. Yin $\mathrm{CT}$, Hulbert $\mathrm{SH}$, Schroeder $\mathrm{KL}$, Mavrodi $\mathrm{O}$, Mavrodi $\mathrm{D}$, Dhingra A, et al. Role of bacterial communities in the natural suppression of Rhizoctonia solani bare patch disease of wheat (Triticum aestivum L.). Appl Environ Microbiol. 2013;79(23):7428-38. https://doi.org/10.1128/AEM.01610-13.

44. Edgar RC. UPARSE: highly accurate OTU sequences from microbial amplicon reads. Nat Methods. 2013;10:996-8.

45. Edgar RC. SINTAX, a simple non-Bayesian taxonomy classifier for $16 \mathrm{~S}$ and ITS sequences; 2016. https://doi.org/10.1101/074161.

46. Cole JR, Wang Q, Fish JA, Chai B, Mcgarrell DM, Sun Y, et al. Ribosomal database project: data and tools for high throughput rRNA analysis. Nucleic Acids Res. 2014;42(D1):D633-42. https://doi.org/10.1093/nar/gkt1244.

47. Oksanen J, Blanchette FG, Friendly M, Kindt R, Legendre P, McGlinn D, et al. Vegan: community ecology package. 2016; https://cran.r-roject.org/web/pa ckages/vegan/index.html.

48. Wickham H. Ggplot2: elegant graphics for data analysis. Springer-Verlag New York. ISBN 978-3-319-24277-4, 2016; https://ggplot2.tidyverse.org.

49. Love MI, Huber W, Anders S. Moderated estimation of fold change and dispersion for RNA-seq data with DESeq2. Genome Biol. 2014;15(12):550. https://doi.org/10.1186/s13059-014-0550-8.

50. Valdes N, Soto P, Cottet L, Alarcon P, Gonzalez A, Castillo A, et al. Draft genome sequence of Janthinobacterium lividum strain MTR reveals its mechanism of capnophilic behavior. Stand Genomic Sci. 2015;24:110.

51. Mazzola M. Assessment and management of soil microbial community structure for disease suppression. Annu Rev Phytopathol. 2004;42(1):35-59. https://doi.org/10.1146/annurev.phyto.42.040803.140408.

52. Kinkel LL, Bakker MG, Schlatter DC. A coevolutionary framework for managing disease-suppressive soils. Annu Rev Phytopathol. 2011;49(1):4767. https://doi.org/10.1146/annurev-phyto-072910-095232.

53. MacNish GC. Changes in take-all (Gaeumannomyces graminis var. tritici), rhizoctonia root rot (Rhizoctonia solani) and soil pH in continuous wheat with annual applications of nitrogenous fertilizer in Western Australia. Aust J Exp Agric. 1988;28(3):333-41. https://doi.org/10.1071/EA9880333.
54. Roget DK, Coppi JA, Herdina Gupta WSR. In: Magarey RC, editor. Assessment of suppression to Rhizoctonia solani in a range of soils across SE Australia, in First Australasian SoilBorne Diseases Symposium. Brisbane: QLD: BSES; 1999.

55. Schillinger WF, Paulitz T. Natural suppression of Rhizoctonia bare patch in a long-term no-till cropping systems experiment. Plant Dis. 2014;98(3):389-94. https://doi.org/10.1094/PDIS-04-13-0420-RE.

56. Barnett SJ, Roget DK, Ryder MH. Suppression of Rhizoctonia solani AG-8 induced disease on wheat by the interaction between Pantoea, Exiguobacterium, and Microbacteria. Aust J Soil Res. 2006;44(4):331-42. https://doi.org/10.1071/SR05113.

57. Donn S, Almario J, Mullerc D, Moenne-Loccoz Y, Gupta WSR, Kirkegaard JA, et al. Rhizosphere microbial communities associated with Rhizoctonia damage at the field and disease patch scale. Appl Soil Ecol. 2014;78:37-47. https://doi.org/10.1016/j.apsoil.2014.02.001.

58. Radhakrishnan R, Hashem A, Abd Allah EF. Bacillus: a biological tool for crop improvement through bio-molecular changes in adverse environments. Front Physiol. 2017;8:667.

59. Elshakh ASA, Anjum SI, Qiu W, Almoneafy AA, Li W, Yang Z, et al. Controlling and defence-related mechanisms of Bacillus strains against bacterial leaf blight of rice. J Phytopathol. 2016;164(7-8):534-46. https://doi. org/10.1111/jph.12479.

60. Elshaghabee FMF, Rokana N, Gulhane R, Sharma C, Panwar H. Bacillus as potential probiotics: Status, concerns, and future perspectives. Front Microbiol. 2017:8:1490. https://doi.org/10.3389/fmicb.2017.01490.

61. Weller DM, Raaijmakers JM, Gardener BBM, Thomashow LS. Microbial populations responsible for specific soil suppressiveness to plant pathogens. Annu Rev Phytopathol. 2002;40(1):309-48. https://doi.org/10.1146/annurev. phyto.40.030402.110010.

62. Berendsen RL, Pieterse CMJ, Bakker PAHM. The rhizosphere microbiome and plant health. Trends Plant Sci. 2012;17(8):478-86. https://doi.org/10.1016/j. tplants.2012.04.001.

63. Santhanam R, Luu VT, Weinhold A, Goldberg J, Oh Y, Baldwin IT. Native root- associated bacteria rescue a plant from a sudden-wilt disease that emerged during continuous cropping. Proc Natl Acad Sci U S A. 2015; 112(36):E5013-20. https://doi.org/10.1073/pnas.1505765112.

64. Finkel OM, Castrillo G, Paredes SH, González IS, Dangl JL. Understanding and exploiting plant beneficial microbes. Curr Opin Plant Biol. 2017;38:155-63. https://doi.org/10.1016/j.pbi.2017.04.018.

65. Gu Y, Wei Z, Wang X, Friman VP, Huang J, Wang X, et al. Pathogen invasion indirectly changes the composition of soil microbiome via shifts in root exudation profile. Biol Fertil Soils. 2016;52(7):997-1005. https://doi.org/10.1 007/s00374-016-1136-2.

66. Lanoue A, Burlat V, Henkes GJ, Koch I, Schurr U, Röse US. De novo biosynthesis of defense root exudates in response to Fusarium attack in barley. New Phytol. 2010;185(2):577-88. https://doi.org/10.1111/j.1469-8137.2 009.03066.x.

67. Nishioka T, Elsharkawy MM, Suga H, Kageyama K, Hyakumachi M, Shimizu M. Development of culture medium for the isolation of Flavobacterium and Chryseobacterium from rhizosphere soil. Microbes Environ. 2016;31(2):10410. https://doi.org/10.1264/jsme2.ME15144.

68. Nishioka T, Marian M, Kobayashi I, Kobayashi Y, Yamamoto K, Tamaki K, et al. Microbial basis of Fusarium wilt suppression by Allium cultivation. Sci Rep. 2019;9(1):1715. https://doi.org/10.1038/s41598-018-37559-7.

69. Shen Z, Penton CR, Lv N, Xue C, Yuan X, Ruan Y, et al. Banana Fusarium wilt disease incidence is influenced by shifts of soil microbial communities under different monoculture spans. Microb Ecol. 2018;75(3):739-50. https:// doi.org/10.1007/s00248-017-1052-5.

70. De Vleesschauwer D, Höfte M. Using Serratia plymuthica to control fungal pathogens of plants. CAB Reviews. 2003;2(46):189-257.

71. Scherwinski K, Wolf A, Berg G. Assessing the risk of biological biocontrol agents on the indigenous microbial communities: Serratia plymuthica HRO-C48 and Streptomyces sp. HRO-71 as model bacteria. Biol Control. 2006;52:87-112.

72. Scherwinski K, Grosch R, Berg G. Effect of bacterial antagonists on lettuce: Active biocontrol of Rhizoctonia solani and negligible, short-term effects on nontarget microorganisms. FEMS Microbiol Ecol. 2008;64(1):106-16. https:// doi.org/10.1111/j.1574-6941.2007.00421.x.

73. Purkayastha GD, Mangar P, Saha A, Saha D. Evaluation of the biocontrol efficacy of a Serratia marcescens strain indigenous to tea rhizosphere for the management of root rot disease in tea. PLoS One. 2018;13:1-27.

74. Lakshmanan V, Kitto SL, Caplan JL, Hsueh YH, Kearns DB, Wu YS, et al. Microbe-associated molecular patterns-triggered root responses mediate 
beneficial rhizobacterial recruitment in Arabidopsis. Plant Physiol. 2012; 160(3):1642-61. https://doi.org/10.1104/pp.112.200386.

75. Lupatini M, Korthals GW, de Hollander M, Janssens TKS, Kuramae EE. Soil microbiome is more heterogeneous in organic than in conventional farming system. Front Microbiol. 2017;7:1-13.

76. Tian B, Yang J, Zhang KQ. Bacteria used in the biological control of plantparasitic nematodes: populations, mechanisms of action, and future prospects. FEMS Microbiol Ecol. 2007;61(2):197-213. https://doi.org/10.1111/ j.1574-6941.2007.00349.x

77. Postma J, Schilder MT, Bloem J, Van Leeuwen-Haagsma WK. Soil suppressiveness and functional diversity of the soil microflora in organic farming systems. Soil Biol Biochem. 2008;40(9):2394-406. https://doi.org/10.1 016/j.soilbio.2008.05.023.

78. Fujiwara K, lida Y, Someya N, Takano M, Ohnishi J, Terami F, et al. Emergence of antagonism against the pathogenic fungus Fusarium oxysporum by interplay among non-antagonistic bacteria in a hydroponics using multiple parallel mineralization. J Phytopathol. 2016;164(11-12):853-62. https://doi.org/10.1111/jph.12504.

79. De Souza R, Ambrosini A, Passaglia LMP. Plant growth-promoting bacteria as inoculants in agricultural soils. Genet Mol Biol. 2015;38(4):401-19. https:// doi.org/10.1590/S1415-475738420150053.

80. Patil AS, Kale A, Ajane G, Sheikh R, Patil S. Plant growth-promoting Rhizobium: mechanisms and biotechnological prospective. In: Hansen A, Choudhary D, Agrawal P, Varma A, editors. Rhizobium Biology and Biotechnology. Soil Biology, vol. 50. Cham: Springer; 2017. p. 105-34.

81. Manter DK, Delgado JA, Holm DG, Stong RA. Pyrosequencing reveals a highly diverse and cultivar-specific bacterial endophyte community in potato roots. Microb Ecol. 2010;60(1):157-66. https://doi.org/10.1007/s00248010-9658-x

82. Montalbán B, Croes S, Weyens N, Lobo MC, Pérez-Sanz A, Vangronsveld J. Characterization of bacterial communities associated with Brassica napus $L$ growing on a Zn-contaminated soil and their effects on root growth. Int J Phytoremediation. 2016;18(10):985-93. https://doi.org/10.1080/15226514.201 6.1183566

83. Morais MC, Mucha Â, Ferreira H, Gonçalves B, Bacelar E, Marques G. Comparative study of plant growth-promoting bacteria on the physiology, growth and fruit quality of strawberry. J Sci Food Agric. 2019;99(12):5341-9. https://doi.org/10.1002/jsfa.9773.

84. Natsagdorj O, Sakamoto H, Santiago D, Santiago C, Orikasa Y, Okazaki K, et al. Variovorax sp. has an optimum cell density to fully function as a plant growth promoter. Microorganisms. 2019;7:82.

85. Venturi V, Fuqua C. Chemical signaling between plants and plantpathogenic bacteria. Annu Rev Phytopathol. 2013;51(1):17-37. https://doi. org/10.1146/annurev-phyto-082712-102239.

86. Massalha H, Korenblum E, Malitsky S, Shapiro OH, Aharoni A. Live imaging of root-bacteria interactions in a microfluidics setup. Proc Natl Acad Sci U S A. 2017;114(17):4549-54. https://doi.org/10.1073/pnas.1618584114.

87. Neal AL, Ahmad S, Gordon-Weeks R, Ton J. Benzoxazinoids in root exudates of maize attract Pseudomonas putida to the rhizosphere. PLoS One. 2012; 7(4):e35498. https://doi.org/10.1371/journal.pone.0035498.

88. Pantanella F, Berlutti F, Passariello C, Sarli S, Morea C, Schippa S. Violacein and biofilm production in Janthinobacterium lividum. J Appl Microbiol. 2007; 102(4):992-9. https://doi.org/10.1111/j.1365-2672.2006.03155.x.

89. Lichstein HC, van de Sand VF. Violacein, an antibiotic pigment produced by Chromobacterium violaceum. J Infect Dis. 1945;76(1):47-51. https://doi.org/1 0.1093/infdis/76.1.47.

90. Nakamura Y, Asada C, Sawada T. Production of antibacterial violet pigment by psychrotropic bacterium RT102 strain. Biotechnol Bioprocess Eng. 2003; 8(1):37-40. https://doi.org/10.1007/BF02932896.

91. Haack FS, Poehlein A, Kröger C, Voigt CA, Piepenbring M, Bode HB, et al. Molecular keys to the Janthinobacterium and Duganella spp interaction with the plant pathogen Fusarium graminearum. Front Microbiol. 2016;7:1668.

92. Kehe J, Kulesa A, Ortiz A, Ackerman CM, Thakku SG, Sellers D, et al. Massively parallel screening of synthetic microbial communities. Proc Natl Acad Sci U S A. 2019;116(26):12804-9. https://doi.org/10.1073/pnas.19001 02116.

\section{Publisher's Note}

Springer Nature remains neutral with regard to jurisdictional claims in published maps and institutional affiliations.

\section{Ready to submit your research? Choose BMC and benefit from}

- fast, convenient online submission

- thorough peer review by experienced researchers in your field

- rapid publication on acceptance

- support for research data, including large and complex data types

- gold Open Access which fosters wider collaboration and increased citations

- maximum visibility for your research: over $100 \mathrm{M}$ website views per year

At BMC, research is always in progress.

Learn more biomedcentral.com/submissions 